\title{
The Persistent Gap: New Evidence on the Canadian Gender Wage Gap
}

\author{
by Marie Drolet
}

No. 157

\begin{abstract}
11F0019MPE No. 157
ISSN: 1200-5223

ISBN: 0-660-18342-0
\end{abstract}

Price: $\$ 5.00$ per issue, $\$ 25.00$ annually

Business and Labour Market Analysis Division

24-F, R.H. Coats Building, Ottawa, K1A 0T6

Statistics Canada (613) 951-5691

Facsimile Number: (613) 951-5403

Internet: drolmar@statcan.ca

The paper is available on Internet: (www.statcan.ca)

January 2001

The author wishes to thank Garnett Picot, Maryanne Webber, René Morissette and Lynda Gagné for helpful comments. The opinions expressed is the sole responsibility of the author and not of Statistics Canada. 


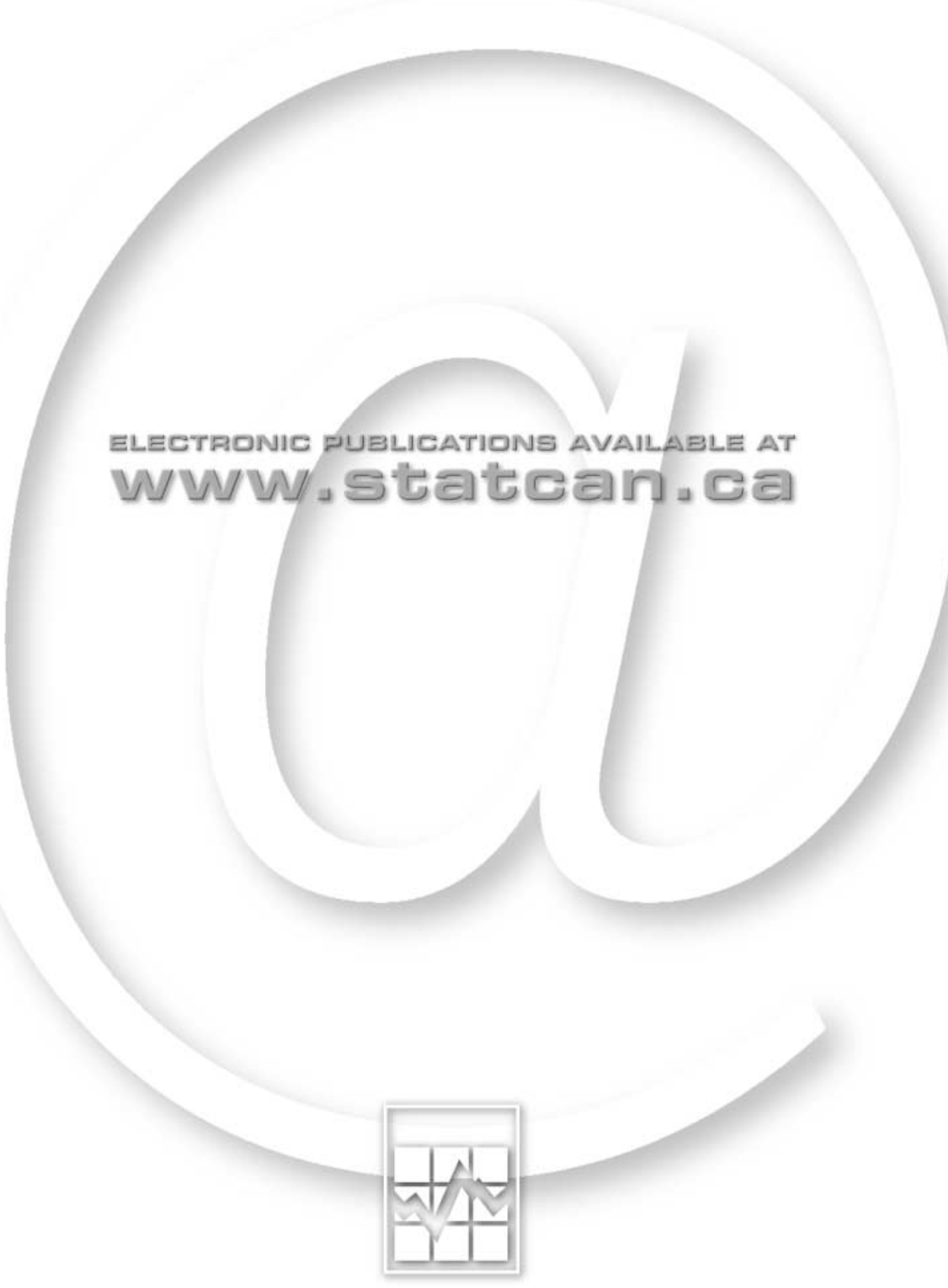




\section{Table of Contents}

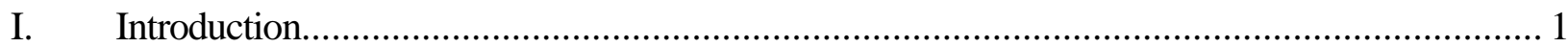

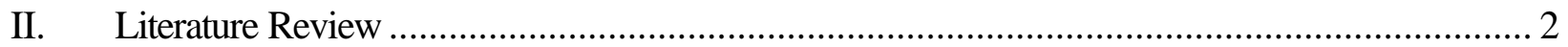

III. Two measures of earnings: annual earnings and hourly wage rates .......................................... 5

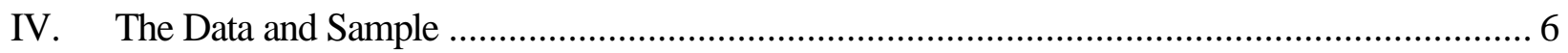

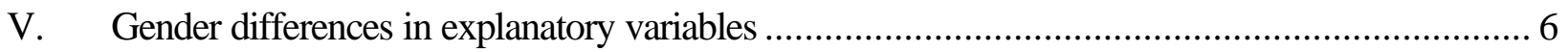

VI. The mean gender differentials: ................................................................................... 9

VII. The Determinants of Wages By Sex................................................................................... 11

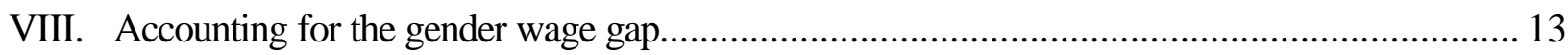

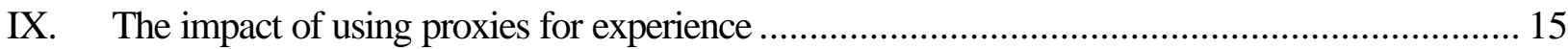

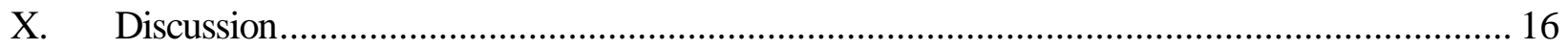

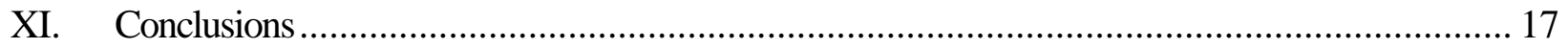

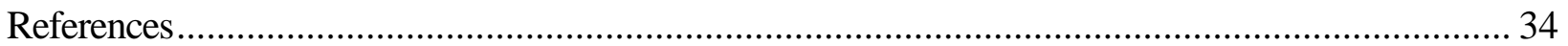




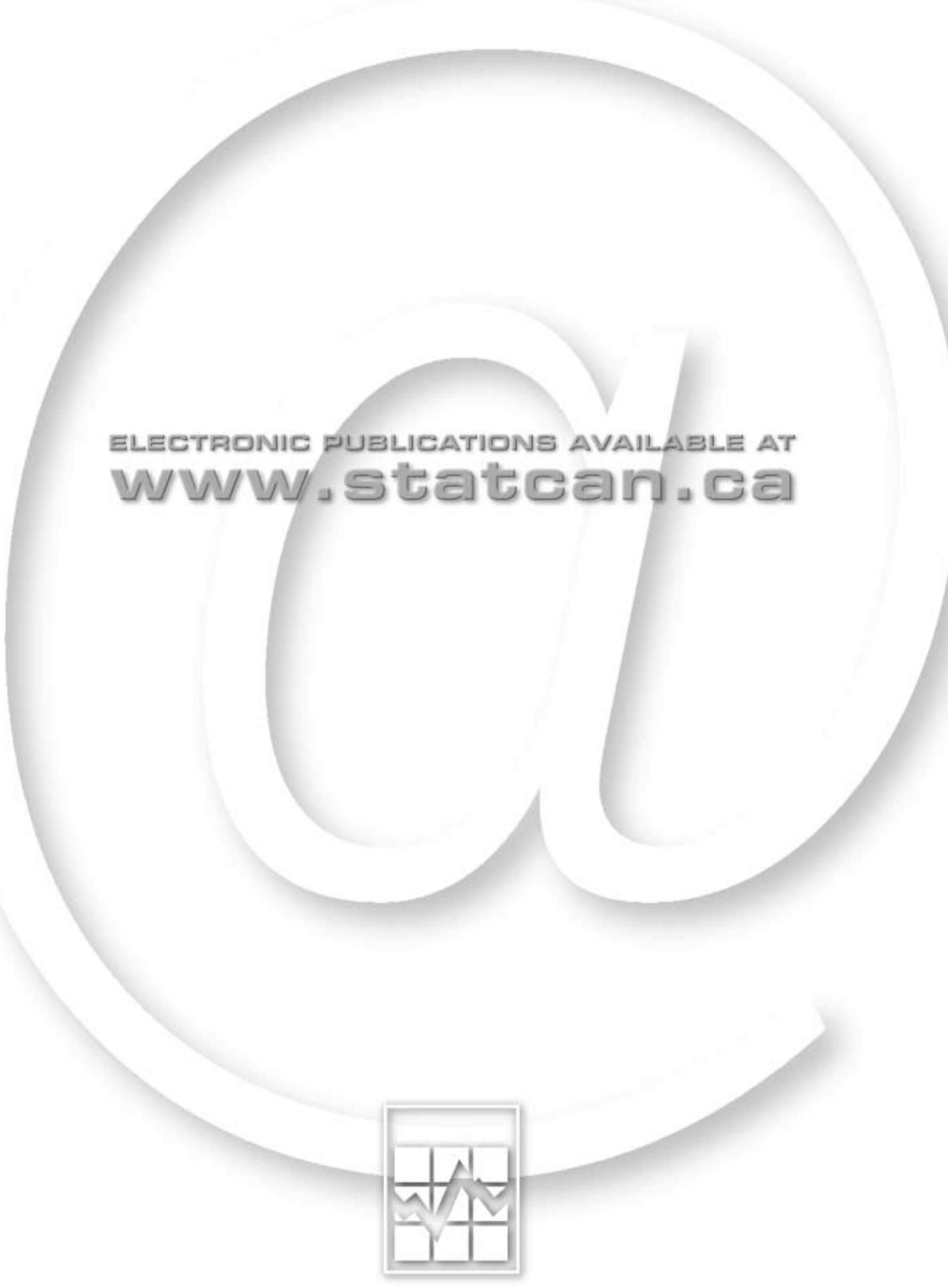




\section{ABSTRACT}

This article uses data from the Survey of Labour and Income Dynamics (SLID) to investigate the extent to which factors not previously explored in the Canadian context account for wage differences between men and women. Like other studies using standard decomposition techniques and controlling for a variety of productivity-related characteristics, the results demonstrate that men still enjoy a wage advantage over women: women's average hourly wage rate is about $84 \%-89 \%$ of the men's average. Unlike other studies, controls for work experience and job-related responsibilities are used. Gender differences in full-year, full-time work experience explain at most, $12 \%$ of the gender wage gap. Gender differences in the opportunity to supervise and to perform certain tasks account for about $5 \%$ of the gender wage gap. Yet despite the long list of productivity related factors, a substantial portion of the gender wage gap cannot be explained.

Many studies rely on measures such as age or potential experience (= age minus number of years of schooling minus six) as a proxy for actual labour market. Neither of these measures account for complete withdrawals from the labour market nor for restrictions on the number of hours worked per week or on the number of weeks worked per year due to family-related responsibilities. The results show that proxies for experience yield larger adjusted gender wage gaps than when actual experience is used.

Keywords: gender earnings: women's wages 


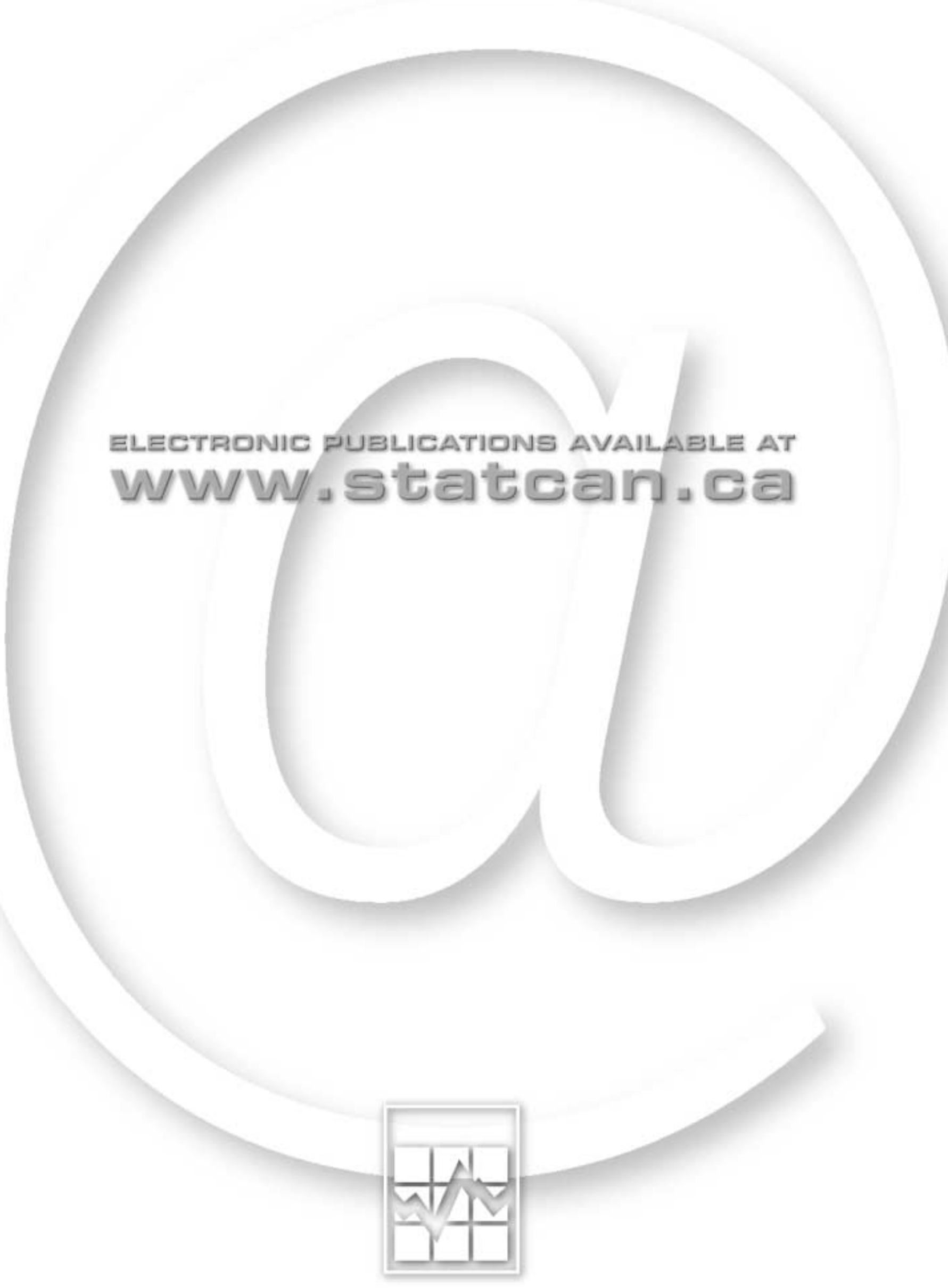




\section{Introduction}

Recent generations have witnessed a profound change in the role of women in the labour market. The rate of female participation in the labour force doubled between 1961 (29\%) and 1996 (60\%). ${ }^{1}$ Women workers in the 1990s have a stronger labour force attachment than their earlier cohorts: they are more likely to postpone childbearing until after they have secured their careers; have fewer children; are less likely to interrupt their careers for 6 months or more after childbirth ${ }^{2}$ and return to work more quickly than new mothers of earlier generations (Gunderson 1998).

These changes in the labour force participation and the commitment of Canadian women have induced dramatic changes in the patterns of family earnings. The traditional concept of male 'breadwinner' and female 'caregiver' no longer symbolizes the Canadian family. Single earner families with only the husband doing paid work changed from the norm in 1967 (58\%) to the exception (18\%) by 1994 (Gunderson, 1998). Women's earnings are an increasingly important component of family earnings. In dual earner families, about one quarter of Canadian women earn more than their male partner (Crompton and Geran, 1995).

Along with these changes, it is a well-documented fact that Canadian women have made substantial gains in their wage-determining or productivity-related characteristics over the past two decades. There has been considerable improvement in women's relative (to men) skills level, in women's quantity of schooling, in women's job experience, and in women's successful infiltration into male-dominated occupations.

Yet despite these pervasive and permanent shifts in female labour force participation, commitment and their relative improvements in wage-determining characteristics, pay differences between men and women persist and continue to be a topical issue in the 1990s. For the past 30 years, the Survey of Consumer Finances (SCF) has documented these pay differences. Among full-year, full-time workers, the female to male earnings ratio was $72.5 \%$ in 1997 , up from $58.4 \%$ in $1967 .^{3}$

Standard decomposition techniques split the gender wage gap into an 'explained' portion (attributable to differences in labour market qualifications and job characteristics) and 'unexplained' portion (attributable to differences in the pay men and women receive for the same characteristic). Most economists focus on gender differences in skills to explain the gender earnings gap.(Coish \& Hale, 1995; Christofides \& Swidinsky, 1994; Gunderson 1998; Wannell, 1989; Baker, Benjamin, Desaulniers, Grant 1995).

1 Data from the Census of Canada in Gunderson, 1998 p.24-26.

2 Almost 9 in every 10 working women who gave birth in either 1993 or 1994 were back on the job within a year. These women took an average of 6.4 months off work. (Perspectives on Labour and Income, Statistics Canada, Autumn 1999, Catalogue number 75-0001-XPE).

3 Data from the Survey of Consumer Finances, The Earnings of Men and Women, Statistics Canada, 1997 Catalogue no. 13-217-XPB. 
The goal of this paper is twofold. The first objective of this paper is to facilitate the move from estimates of gender earnings ratios produced by the Survey of Consumer Finances to estimates of gender wage ratios produced by the Survey of Labour and Income Dynamics. This paper briefly examines the gender pay ratio based on annual earnings - known as the gender earnings gap - using similar definitions and concepts used in the publication of female-male earnings ratios based on SCF data. The paper focuses on the gender pay gap based on hourly wage rates - known as the gender wage gap. The second objective of this paper is to take advantage of the wealth of information gathered by the Survey of Labour and Income Dynamics (SLID) by focussing on factors not previously explored in the Canadian context to explain the gender earnings differential. This may add a substantial dimension to research in the area of women's labour market issues and in the analysis of the gender wage gap.

The plan of the paper is the following. Section II provides a brief literature review of the Canadian evidence on the gender wage gap over the past two decades. Section III documents the two measures of earnings used in this study. Section IV specifies the sample used in our analysis. Section V discusses SLID variables that may explain part of the gender differentials. Section VI examines the gender wage gap and the gender earnings gap. Section VII examines the determinants of wages by gender. Section VIII decomposes the gender wage gap into a portion attributable to gender-specific factors and a portion attributable to differences in the pay men and women receive. Section IX attempts to quantify the impact of using proxies for experience on the gender wage gap. A discussion of the results is presented in Section X. Concluding remarks follow.

\section{Literature Review}

There are numerous Canadian studies estimating the gender wage differential. Although there are significant differences among the studies related to data sources and methodology, there are certain consistent findings. Table 1 highlights some of the main findings of the Canadian literature. ${ }^{4}$

The first unequivocal fact is that the gender earnings differential has declined over time. Using Census data, Baker et al. (1995) find that the full-year full-time female to male yearly earnings ratio increased steadily from 0.60 in 1970 to 0.64 in 1980 to 0.67 in 1990 . This finding is also obtained by Gunderson (1998) who, also using Census data, calculates a similar yearly earnings ratio of 0.63 in 1970, 0.67 in 1980 and 0.72 in 1990 for full-year, full-time workers. Applying a consistent framework to data from the Survey of Consumer Finances (SCF), Baker et al. (1995) find a comparable female to male yearly earnings ratio of 0.64 in 1986 and 0.67 in 1991. Coish and Hale (1995) use data from the 1993 Survey of Labour and Income Dynamics (SLID) and find that women employed full-year full-time earn roughly $79 \%$ of the earnings of equivalent males. Interestingly, their calculation of the gender differential in hourly wage rates using all workers (full-time and part-time workers) produces a

4 This list is meant to provide recent Canadian evidence on the gender wage gap and its respective components. It is not meant to be exhaustive of the literature.

5 Baker et al. (1995) hypothesize that the differences in the Census and the SCF earnings ratio may result from differences in sampling techniques, in the timing of the surveys, and in sample selection exclusions. 
marginally lower ratio of 0.78. Christofides and Swidinsky (1994) encounter a white female-white male earnings ratio of 0.76 using hourly wage rates from the 1989 Labour Market Activity Survey.

Second, a substantial portion of the male-female pay gap cannot be explained by gender differences in observable wage-determining characteristics, that is the gap cannot be explained by the difference in the average value of the wage-determining characteristic $\left(\bar{X}_{m}-\bar{X}_{f}\right)$, evaluated according to the male returns $\beta_{m}$. Baker et al. (1995) find that roughly one quarter of the gender earnings gap in the 1970-1985 period was explained by differences in wage-related characteristics. Gunderson (1998) detects a slight decline in the portion of the gender earnings gap attributable to differences in the wage-determining characteristics: from $35.4 \%$ in 1970 to $29.4 \%$ in 1990 . He concludes that this finding 'suggests that the female work force has become more like the male workforce in its wage determining characteristics and this has helped to narrow the overall earnings gap' (Gunderson, 1998). Christofides and Swidinsky's (1994) estimated share of the gender wage differential attributable to productivity-related factors is $26.6 \%$ - falling between the Baker et al. (1995) and the Gunderson (1998) estimates. Coish and Hale (1995) find only $12 \%$ of the wage gap explained by demographic or human capital characteristics.

Third, most of the improvement in Canadian women's relative pay was accomplished by a decline in the 'unexplained' portion of the gender pay gap. The 'unexplained' component of the wage gap refers to the differences in the pay men and women receive for the same characteristics. Oftentimes, this 'unexplained' component is referred to as an estimate of the gender based labour market discrimination. Baker et al. (1995) decompose the change in gender earnings gap between two periods (t-1) and (t) $\left(\bar{y}_{t}^{m}-\bar{y}_{t-1}^{m}\right)-\left(\bar{y}_{t}^{f}-\bar{y}_{t-1}^{f}\right)$ into a portion attributable to changes in the mean characteristics $\left[\hat{\beta}_{t}^{m}\left(\bar{X}_{t}^{m}-\bar{X}_{t-1}^{m}\right)-\hat{\beta}_{f}\left(\bar{X}_{t}^{f}-\bar{X}_{t-1}^{f}\right)\right]$ and to changes in the returns to those characteristics $\left\lfloor\bar{X}_{t-1}^{m}\left(\hat{\beta}_{t}^{m}-\hat{\beta}_{t-1}^{m}\right)-\bar{X}_{t-1}^{f}\left(\hat{\beta}_{t}^{f}-\hat{\beta}_{t-1}^{f}\right\rfloor\right.$ over the period using the following expression:

$$
\begin{aligned}
& \left.\left(\bar{y}_{t}^{m}-\bar{y}_{t-1}^{m}\right)-\left(\bar{y}_{t}^{f}-\bar{y}_{t-1}^{f}\right)=\mid \hat{\beta}_{t}^{m}\left(\bar{X}_{t}^{m}-\bar{X}_{t-1}^{m}\right)-\hat{\beta}_{f}\left(\bar{X}_{t}^{f}-\bar{X}_{t-1}^{f}\right)\right]+ \\
& {\left[\bar{X}_{t-1}^{m}\left(\hat{\beta}_{t}^{m}-\hat{\beta}_{t-1}^{m}\right)-\bar{X}_{t-1}^{f}\left(\hat{\beta}_{t}^{f}-\hat{\beta}_{t-1}^{f}\right]\right.}
\end{aligned}
$$

They find that between 1970 and 1980 most of the decline in the gap is due to a decline in the relative returns to wage-determining factors; between 1980 and 1985 most of the decline in the gap is due to changes in the relative characteristics of men and women; and finally between 1985 and 1990, the decline in the difference in returns is important. ${ }^{6}$

The literature puts forth several common explanations for the decline in the 'unexplained' component. The first explanation is a widespread decline in discrimination towards women in the labour market. This may take the form of changing societal and/or employer attitudes towards women at work.

6 Baker et al. (1995) find that 50\% - 114\% of the decline in the gap between 1970 and 1980 is due to the difference in returns; $65 \%-88 \%$ of the decline in the gap between 1980 and 1985 is due to differences in characteristics; 62\% $85 \%$ of the decline in the gap between 1985 and 1990 is due to differences in returns. These numbers are taken from Baker et al. Table 2 . 
Employers are constantly making decisions with imperfect information and may use gender to predict future work commitment. Some firms may hesitate to hire women because women have, on average, more career interruptions and more absences due to family reasons than men. Consequently, statistical discrimination against the individual woman may result. This would be especially true in firms with substantial hiring and/or training costs and where wages are generally higher. Insofar as the increase in women's attachment to the labour force induces changes in employer behaviour, women's access to high-paying jobs will improve due to decreases in statistical discrimination.

The second explanation for the decline in the 'unexplained' component is related to differences in unmeasured attributes, skills or preferences. Most data sets do not contain sufficient information on other important determinants of the gender pay gap. The Survey of Labour and Income Dynamics offers a number of variables not gathered by other data sources that may be considered important determinants of the gender pay gap. Section III examines these variables and justifies their inclusion.

If there were no unexplained component to the gender wage gap, that is, if there were no differences in the pay men and women receive for the same characteristics, females would still earn less than men but only slightly (Table 1, Column 7). The earnings ratio net of differences in the returns to the same characteristics would range from about $85 \%$ in 1970 from the Gunderson (1998) to around 90\% for the entire 1970-1990 period using the numbers from Baker et al. (1995) and 93\% using Christofides and Swidinsky (1994). Again, the exception is the Coish and Hale study that estimates the earnings ratio without the unexplained component to be $97 \%{ }^{7}$

Finally, estimates of the gender pay gap are sensitive to the earnings measure used, to the choice of method, to the population selected, and in the specification thus rendering comparisons difficult. Baker et al. (1995) observe that the female-male earnings ratio after controlling for differences in observable characteristics hovers around $70 \% .{ }^{8}$ On the other hand, Gunderson (1998) notices that the ratio increases from $74 \%$ in 1970 to $80 \%$ in 1990. Christofides and Swidinsky (1994) and Coish and Hale (1995) produce gender wage ratios after controlling for differences in observable characteristics closer to that of Gunderson (1998): roughly 82\% in 1989 and 80\% in 1993 respectively. The different studies also produce somewhat different estimates of the 'unexplained' earnings differential throughout the 1970-1990 period (Table 1, Column 6).

7 If men and women received the same pay for similar characteristics, the entire gender earnings gap would be attributable to differences in productivity-related factors. In other words, we compare the wage men earn $\left(\bar{W}_{m}=\bar{X}_{m} \hat{\beta}_{m}\right)$ to the hypothetical wage women would receive if they were paid according to the male wage structure given their own characteristics $\left(\bar{W}_{f}^{*}=\bar{X}_{f} \hat{\beta}_{m}\right)$.

8 To calculate the female-male earnings ratio after controlling for differences in characteristics, ratio $=$ $\exp \left[-\left(\beta_{m}-\beta_{f}\right) \bar{X}_{f}\right]$ 


\section{Two measures of earnings: annual earnings and hourly wage rates}

Up until 1997, Statistics Canada published female-male earnings ratios using data from the Survey of Consumer Finances (SCF). Among full-year, full-time workers ${ }^{9}$ the female-male annual earnings ratios ranged from $58.4 \%$ in 1967 to $72.5 \%$ in 1997 . Among all persons receiving a wage, a salary or net income from self-employment, the female-male earnings ratio ranged from $46.1 \%$ in 1967 to $63.8 \%$ in 1997 (Table 2).

The size of the gender gap reported by the SCF may be contaminated by differences in the number of hours worked per week among full-year, full-time (FYFT) male workers and FYFT female workers. The SCF definition of a FYFT worker is a person who works 30 hours or more per week for 49-52 weeks in the reference year. But there is considerable variation in the number of hours usually worked per week among full-time workers - using data from the Labour Force Survey, men employed full-time in December 1996 usually worked 43.6 hours per week while women employed full-time usually worked 39.6 hours per week.

Using the National Graduates Survey, Wannell and Caron (1994) find that among recent graduates, fulltime female workers worked an average of 2.5 - 4 hours less per week than their male counterparts. Adding weekly hours to their wage equation, Wannell and Caron (1994) demonstrate that the wage gap among graduates is smaller than the earnings gap.

The definition of annual earnings may render the size of the gender pay gap difficult to interpret. The earnings ratios based on the SCF data define total earnings as consisting of wages and salaries and/or net income from self-employment from all sources. With this definition of earnings, it is difficult to pinpoint the source of the gender gap in annual earnings. Is the gender gap in annual earnings the result of differences in the base pay men and women receive for a given job? Or in net income from selfemployment? Or in the premiums associated with over-time work? Or in multiple jobs held?

Hourly wage rates are a superior measure to annual earnings when determining the gender pay gap for several reasons. First as noted earlier, when annual earnings measures are used, the researcher is forced to restrict attention to full-year full-time workers to avoid some of the of problems associated with the number of hours worked per week and the number of weeks worked per year. Hourly wage rates avoid this problem altogether. Second, using hourly wage rates allows the researcher to determine differences in the pay men and women receive for similar jobs - that is, to accurately control for job characteristics such as tenure, industry, occupation or union status. This cannot be done precisely when using total annual earnings. Because total annual earnings are the summation of wages and salaries from all jobs in the reference year, it becomes difficult to examine the impact of particular job characteristics. The best that can be done when using total annual earnings is to use job information on the 'main' job and to define main job as the job with the greatest number of work hours or the job accounting for the greatest share of earnings.

9 The SCF definition of a full-year full-time worker is a person who works 30 hours or more per week for 49-52 weeks in the reference year. 


\section{The Data and Sample}

We use the 1997 data from the Survey of Labour and Income Dynamics (SLID) to extract two samples - the first sample analyzes the gender wage gap, and the second sample analyzes the gender earnings gap.

The analysis of the gender wage gap consists of paid workers, aged 18-64 and who are not enrolled as full-time students in the reference year. Self employed individuals, individuals for whom hourly wage data or earnings data is not known, individuals for whom the full-year full-time work experience equivalent ${ }^{10}$ (FYFTE) is not known and individuals for whom total usual hours worked in the job during the year is not known ${ }^{11}$ are excluded. The analysis is based on 28,741 jobs $-14,839$ jobs held by men and 13,902 jobs held by women. This sample is used for both cross-tabulations and for the multivariate analysis of the gender wage gap.

The second sample is selected for cross-tabulations of the gender earnings gap and imposes the additional restrictions of workers employed full-year (53 weeks per year) full-time (130 hours or more each month). This sample consists of 15,687 individuals $-9,020$ men and 6,667 women. For workers holding more than one job during the reference year, the job characteristics attributable to the main job (where the main job is defined as the job with the greatest number of usual hours worked during the reference year) are used for the analysis.

\section{Gender differences in explanatory variables}

\section{Work experience}

Past research on gender pay differentials have suffered from serious data limitations. Oftentimes age or age minus schooling minus 6 is used as a proxy for the acquisition of general human capital skills or as a proxy for potential work experience. This is problematic since these measures tend to overstate the actual experience of women. That is, no account is taken of interruptions in the labour force participation of women for child-rearing purposes (i.e. complete withdrawals from the labour market) or of any restrictions on the hours of work per week or on the number of weeks worked per year.

SLID offers a measure of actual labour market experience - the full-year full-time equivalent (FYFTE). This measure incorporates all work experience by including information on the number of hours worked per week (i.e. full-time or part-time job) and for the number of weeks worked per year (fullyear or part-year) for all jobs held by the individual. ${ }^{12}$

10 The exclusion of observations with unknown full-year, full-time work equivalent is not believed to produce any sample selection bias. These exclusions were, to a fair extent, randomly distributed throughout the population.

11 Since all jobs held during the reference year are included in the analysis, the cross-sectional job weights were standardized according to the annual hours worked in the job. This is done to avoid over-representing short tenure jobs.

12 The SLID measure is calculated as follows: 
The SLID measure of FYFTE work experience is a good estimate of the actual labour market experience of workers since it incorporates all work - but it is far from perfect. Although, as we will see, it 'explains' a sizable portion of the gender pay gap, there are two important drawbacks to this measure.

First, information on the continuity of work experience, on the duration of labour force withdrawals, on the frequency of withdrawal and on the timing of a withdrawal is missing.

It is a well-documented fact that men and women differ considerably in the amount of time they work and in the continuity of their work experience. Women are more likely to combine periods of paid work with periods of labour force withdrawal for family-related reasons. According to Corcoran and Duncan (1979), this may influence the pay women receive in several ways. First, since women are less likely to work continuously than men, they may have lower levels of job tenure- a factor that influence wages. Second, human capital skills may depreciate during long periods of labour force withdrawals. As a result, women returning to the same employer after an interruption in employment may be less likely to be promoted, and those women not returning to the same employer may be forced to accept wages that are lower than the wages they received prior to their withdrawal. Third, women expecting several withdrawals from the labour force may postpone training, or may decide to accept low-wage jobs in industries or occupations that are easy to enter and that have little or no penalty for exiting. Fourth, the timing of labour force withdrawals may impact wages. The acquisition of job-related skills is usually concentrated at the start of careers - which generally coincides with decisions regarding children. Murphy and Welch (1990) find that a significant portion of real lifetime earnings growth occurs during the first years after graduation. If this is the case, then the timing of labour force withdrawals may have important long run implications for future earnings patterns / lifetime earnings among men and women.

Table 3 illustrates the differences in work experience that men and women bring to the labour market. Compared to men, the average woman has 3.9 years less FYFTE work experience and has 1.3 fewer years of present employer tenure. Alternatively, men spend a greater proportion of their potential years of work experience working full-time than women (94\% versus $75 \%$ ).

Second, the definition of full-year and full-time used for the calculation of FYFTE work experience, may be problematic. Full-year refers to working at least 6 months and full-time refers to working at least 30 hours per week in a calendar year. As noted earlier, there is considerable variation in the number of hours usually worked per week among full-time workers. For instance, person A works 45 hours per week for 12 months while person B works 32 hours per week for 7 months. Under the SLID measure of FYFTE, each person would have 1 year of FYFTE experience despite the significant variation in their work experience. As well, the measure of FYFTE work experience does not account for shortterm labour force withdrawals of less than 6 months in a given year. Marshall (1999) shows that almost $40 \%$ of women take less than 6 months off work after giving birth. If these unrecorded work interruptions and hours of work become more important as experience increases, then the measure of FYFTE work experience may become less accurate in its ability to reflect the relative amount of work done be men and women.

FYFTE experience = number of years worked full-year, full time $+0.5 *$ (number of years worked part-year, full-time $)+0.5 *$ (number of years worked full-year, part-time $)+0.25^{*}$ (number of years worked part-year, parttime). 


\section{Job-related responsibilities}

SLID contains information on work responsibilities such as supervisory positions and work-related tasks such as workers' influence on budgeting or staffing, pay and promotion, and deciding work for others. As long as there exist differences in the opportunities for obtaining supervisory positions and/or that there exists differences in the wage premiums offered to men and women in these jobs, gender wage differentials will exist.

Table 4 shows how men and women experience different opportunities in their job-related responsibilities. Compared to the jobs men hold, women are less likely to be employed in jobs having supervisory responsibilities (35.2\% and $24.8 \%$ respectively) and are less likely to be employed in jobs that involve budget and/or staffing decisions (21.7\% and $15.7 \%)$.

\section{Educational attainment}

One advantage of SLID is information on the major field of study category for the highest completed level of post secondary education. Table 5 shows the diverging percentage distributions ${ }^{13}$ and the gender composition ${ }^{14}$ of each major field of study. Not surprisingly, many fields of study are dominated by either men or women and this may impact the gender pay gap. For instance, graduates of engineering, applied sciences technologies and trades fields are mostly men while on the other hand, women are over-represented among college graduates with a commerce or business administration degree, and among health and education fields. Since wages differ by field of study, the choice of major field of study by men and women may account for some of the gender pay gap.

\section{Other explanatory variables}

This paper incorporates several explanatory variables other than gender (and those mentioned previously) that are generally considered to influence wages. Marital status and age of youngest family member is meant to account for differences in household responsibilities and in the division of labour within the home. Region and urban size class is designed to capture inter-regional wage differentials. Since large firms pay more than small firms (Morissette, 1991) and since women have a lower probability of working in large firms, firm size is included as a potential explanation of the gender wage gap. Finally, union status attempts to account for differences in wage structures between non-unionized and unionized sectors.

\footnotetext{
13 The percentage distribution shows how the male and female workforces are split across different major fields of study.

14 The gender composition shows the incidence of men and women in each field of study.
} 


\section{The mean gender differentials:}

Table 6 highlights the gender differences in hourly wages (also referred to as the gender pay gap) and in the annual earnings (alternatively, referred to as the gender earnings ratio) by a number of demographic and labour market characteristics while Table 7 examines the gap by job characteristics.

\section{A. Gender wage gap: Hourly wage rates}

In 1997, women workers earned on average $\$ 15.12$ per hour while male workers received $\$ 18.84$. In other words, women earned about $80 \%$ of the average male hourly wage (Table 6).

The ratio of female-to-male hourly wage rates is highest (that is, the pay gap is smallest) -among young workers (Table 6). Young females aged 18-24 (25-34) earn about 85\% (86\%) of comparable male earnings. The small pay gap between young men and young women may be attributable to the fact that these workers are new entrants into the labour market with similar skills and similar labour market experience. As well, the effect of career interruptions, job advancement and differentiated household responsibilities have not yet taken place. There are greater differences in FYFTE work experience as workers age: men aged 45-54 (55-64) have 6.4 (13.1) more years of FYFTE work experience than comparable women. This may explain why the gender pay ratio falls steadily with age - women aged 45-54 earn about $75 \%$ of the average hourly wage rate of men 45-54. Another possibility is that gender differences in educational attainment may be larger among older cohorts of workers than among younger ones. Older cohorts of women may also have a higher concentration in low-paid occupations than younger cohorts of women. As well, older women workers are also part of a generation where their upward mobility in the workforce was less common, regardless of their work experience.

The gender pay gap is smallest amongst single, never married men and women (96\%) and highest among married men and women (77\%) (Table 6). The smaller pay gap between single, never married men and women may be partly related to age as well as to the fact that they have similar commitments to the labour force and to household responsibilities. The large pay gap between married men and married women may be partially explained by the conflict married women face between their family and their career. The hours worked by married women are more likely to be part-time than the hours worked by married men. ${ }^{15}$ Part-time work may allow women to choose jobs that are closer to home or that coincide with their children's school hours. As long as there is a premium associated with full-time work, women who choose to work part time to balance family and work responsibilities are willing to accept lower wages in exchange for flexible or shorter work hours. These reasons may partially explain the higher gender wage gap among married women and married men.

As noted earlier, one advantage of the SLID data set is the information on actual work experience as measured by the full-year, full-time equivalent (FYFTE) variable. At low levels of work experience, the gender pay gap is small: women with 0-2 years of work experience earn $96 \%$ of the average male hourly wage rate with a similar level of work experience (Table 6). But, interestingly, the gender pay gap gets larger as the number of FYFTE work experience gets larger. This mirrors the findings of Finnie and

15 About $15.4 \%$ of hours worked by married women are part-time compared to $2.1 \%$ of hours worked by married men. 
Wannell (1999). Using a sample of recent post secondary graduates from the National Graduates Survey, they find that the gender pay gap is relatively small two years after graduation (93\%) but widens $2-5$ years after graduation $(84 \%){ }^{16}$

The fact that the gender wage gap increases as FYFTE increases may be attributable to several factors. First, women are more likely to span their work experience over a longer period of time than men women with 10-19 years of FYFTE work experience are, on average, 4 years older that men with similar levels of FYFTE experience. Second, the longer the actual work experience, the greater the possibility that women had frequent interruptions, long withdrawals from the labour force and shorter job tenure - factors that influence wages and may increase the gender wage gap. Finally, part of the difference may also be due to the fact that workers with high levels of FYFTE work experience are generally older, which, for reasons mentioned above, leads to higher wage gaps.

The gender pay gap differs among education levels (Table 5). Compared to the entire population, the gender pay gap is lowest among university graduates - women earn roughly $85 \%$ of the average hourly wage rate of university educated men. This is not surprising since men and women in this population have similar endowments of wage-determining skills and similar levels of commitment to the labour market. However, this is a partial explanation since the gender wage gap is $81 \%$ among persons with a university degree higher than a bachelors. ${ }^{17}$

The type of tasks performed and the work responsibilities of male and female workers may also influence the gender pay gap (Table 4). As noted earlier, men are more likely to hold supervisory positions and among supervisors, male supervisors are more likely to have the added responsibilities of influencing pay/promotion and of deciding work for others. This may partially explain why male supervisors enjoy a higher hourly wage rate than female supervisors.

The gender wage gap is smaller among unionized workers than non-unionized workers: unionized (nonunionized) women workers earn $87 \%$ (77\%) of the average unionized (non-unionized) male worker (Table 7). ${ }^{18}$ It is a well documented fact that unions tend to compress the wage structure by reducing wage differentials among workers with different characteristics and by standardizing the wages of similar workers across establishments in the same industries or occupations (Meng, 1990). Unions typically increase the wages of those at the lower end of the pay scale proportionately more than those at the upper end (Gunderson and Riddell, 1993).

The gender pay gap does not decline as job tenure in the current job increases (Table 7). That is, the ratio is not higher for high levels of accumulated experience at the current job. While the wages of both

16 Using data from the National Graduate Survey, Finnie and Wannell (1999) find that for 1990 graduates, the gender wage gap is $93 \%$ in 1992 and $84 \%$ in 1995 . They conclude that "these findings have interesting implications for the longer term earnings profiles of graduates as they suggest that longer run (permanent) reductions in the earnings gap amongst cohorts of graduates might not be nearly as great as immediate post-graduation record suggest."

17 This may be attributable to the concentration of women in degree programs in lower paying fields.

18 A unionized worker refers to workers covered by a collective bargaining agreement or a union member. 
men and women increase with tenure, the gender wage gap may not necessarily decrease with tenure. The impact of job tenure may be confounding the influence of other important variables such as industry, occupation, age or labour market experience.

Women who work part-time earn $92 \%$ of the average male part-time hourly wage rate (Table 7). But the aggregated gender pay gap hides interesting heterogeneity among part-time workers. Examining the gender distributions in part-time work hours by industry and occupation reveals that for men, part-time work hours are concentrated in the low-wage consumer services industry (36\%) and in service occupations $(24 \%)$. For women, part-time work hours are concentrated in the consumer services industry (33\%), low-wage clerical occupations (27\%) and in the relatively high-wage natural or social science occupations (29\%). This finding casts doubt on such explanations of the small overall gender pay gap among part-time workers as owing mainly to the fact that these workers possess little skills and are clustered in low-wage industries and occupations. Rather, the relatively small part-time gender wage gap may be partially due to the relatively high earnings of a subset of part-time female workers.

\section{B. Gender earnings gap: Annual Earnings}

In 1997, the average full-year, full-time female worker earned $\$ 31,506$ per year while the average FYFT male worker received $\$ 46,108$. In other words, the average women worker earned about $68 \%$ of the average male annual earnings (Table 6). As pointed out before, gender pay gap analyses based on annual earnings measures suffer from serious data problems associated with assumptions on the number of work hours per week.

Despite the problems of using annual earnings, all previous relationships between the gender wage gap and selected measures are maintained for the gender earnings gap. Namely, the gender earnings gap is smaller among younger, better-educated, single never married, unionized workers, public sector workers and workers with low levels of FYFTE work experience.

\section{The Determinants of Wages By Sex}

There is no 'universally accepted' set of conditioning variables that should be included in a wage equation. Most economists control for productivity-related factors, such as education and work experience, when assessing the gender earnings differentials. Education is considered a productivity enhancing investment designed to improve earnings. Job tenure with present employer is considered a measure of job-specific training - employers investing in their employees are likely to pay a higher wage than the market wage in order to reduce turnover.

Some economists argue that control variables such as occupation and industry should be included. Yet these control variables may themselves be the result of discrimination and may lead to an 'overjustification' of pay differentials (Wannell, 1989). In other words, the overcrowding of females into relatively low-wage occupations does explain part of the earnings gap. 
Unlike other studies, our models are fully-interacted with gender. ${ }^{19}$ Our analysis follows that of other studies and begins with a 'standard' wage equation that includes traditional human capital variables such FYFTE work experience, education level and major field of study, job tenure, marital status and age of youngest family member. In a second specification, controls for part-time status, union status, region, geographical size, and firm size are added. Work responsibilities are included in specification 3. In specification 4, we estimate a model that includes controls for occupation and industry. ${ }^{20}$ The results may be summarized as follows.

First, in all specifications, the differential intercept term for women is significantly less than that of men. In other words, there exist large, significant differences in the earnings of men and women that are unrelated to the choice of explanatory variables in this study.

Second, the relationship between the various independent variables and wages are consistent across gender. Results not shown here indicate that the wages of men and women increase monotonically with FYFTE work experience, education level ${ }^{21}$ and job tenure. Wage levels are also higher in unionized jobs, in large (500+) firms, among full-time workers and in jobs with greater responsibilities.

Third, after controlling for a variety of productivity-related characteristics, the returns to each additional year of FYFTE work experience is similar for men and women. That is, for each additional year of FYFTE work experience, the hourly wage rates of men (women) increase about $0.7 \%(0.8 \%){ }^{22}$

There also appears to be a significant gender difference in the returns to work responsibilities after controlling for a number of other factors. Male (female) workers who influence budget and staffing decisions earn about $5 \%-8 \%(8 \%-11 \%)$ more than those who do not participate in the decision

19 In most studies of the gender earnings differential, wage equations for men and women are run separately. In this study, a fully interacted regression equation is run. That is, we run one equation with a complete set of female interaction terms. This method has two main advantages over running two separate equations. First, the individual regressions for men and women can be easily deduced from the single equation (Appendix 1). Second, we can use the single regression to test a variety of hypotheses. For instance, we can test whether the female differential intercept / slope is statistically significant - this pinpoints the source(s) of the difference. The t test can tell us, for example, if the returns to a university education is the same for men and women but we can also use the $\mathrm{F}$ test to determine if the female returns to the set of education variables is significant.

20 A variety of hypotheses on the female differential intercept and slope coefficients were tested. In Specifications 1 to 3 , the female returns on all sets of coefficients differed significantly (at the 5\% level) from the returns of men. In Specification 4, the female returns to FYFTE experience, union status, tenure and job duties were not statistically different (at the 5\% level) from those of men. The model was re-estimated omitting those female differential terms.

21 The only exception is in Specification 4 where male high school graduates earn slightly more than males who have some post secondary education.

22 A simple $t$ test on the female differential FYFTE experience coefficient shows that, for at least 3 out of 4 specifications, the female return for each additional year of FYFTE work experience is significantly (at the 5\% level) higher than for men but there appears to be no empirical difference. When controls for industry and occupation are added (Specification 4), there is no significant difference in the returns men and women receive for each additional year of FYFTE experience. 
making. ${ }^{23}$ As well, male (female) supervisors that influence the pay and promotion of their staff or decide work for others earn $6 \%-9 \%(5 \%-6 \%)$ more than comparable workers not in supervisory positions and earn $3 \%$ more than supervisors that do not perform these tasks. ${ }^{24}$ Male and female supervisors that perform both duties earn 11\%-13\% more than comparable workers not in supervisory positions and earn roughly $8 \%$ more than supervisors that do not perform these tasks.

Fourth, the returns women receive to education level, major field of study, tenure, marital status, age of youngest family member, part-time status, union status, firm size, industry and occupation differ significantly from those of men. Appendix 2 Table 1 summarizes which characteristics yield significantly different returns between men and women. The positive interactions show the attributes for which women are compensated relatively better than men while the negative interactions illustrate the characteristics that women are rewarded relatively less than men. On the one hand, female returns are significantly higher than those for men at each level of present employer tenure, for part-time status, in small firms, and in Toronto or Vancouver. An examination of differences in the returns to each major field of study shows that women receive significantly higher returns to college level health science and technology; and to university studies in educational, recreational services, humanities and related fields, and social science field. On the other hand, married women and women with less than a high school education fare relatively worse than similar men.

\section{Accounting for the gender wage gap}

Although men and women differ in ways that may affect their productivity, it does not necessarily mean that these differences 'explain' the gender pay gap. The pay gap can only be explained if the differences in the factors in question are themselves important determinants of the pay men and women receive. The wage gap between men and women may be the result of either differences in their productivity-related characteristics (Section V) or differences in the compensations they receive for the same productivityrelated characteristics (Section VII). The unadjusted gender gaps discussed in Section VI do not control for differences in the composition of the male and female workforce and in their wagedetermining characteristics. In this section, multivariate analysis techniques are employed to control for the effect of several factors simultaneously.

The dependent variable is the natural logarithm of hourly wage rates. Each coefficient is the percentage change in hourly wage rates associated with a one-unit change in the explanatory variable. Table 8 presents the decomposition of the mean hourly wage differential into an 'explained' portion and an 'unexplained' portion for several different specifications. Table 9 shows the fraction of the gender wage

23 The $\mathrm{t}$ test on the budget and staffing decision variable in both Specifications 3 and 4 , shows that there is a significant difference in the returns of men and women at the $5 \%$ level of significance.

24 In Specifications 3 and 4 that incorporate work responsibilities a joint test of significance was conducted on the set of differential slope coefficients for women related to work responsibilities. In Specification 3 , the F test concluded that the female returns to work responsibilities differed significantly from those of men at the $5 \%$ level. However, in Specification 4, the F test concluded that the female returns to work responsibilities were not significantly different from those of men. 
gap attributable to various factors. The technical details of the decomposition method employed in this study are outlined in Appendix 1 while Appendix 2 Table 1 presents the results of various hypothesis tests.

Each subsequent specification includes additional variables in an attempt to explain the gender wage gap. Several interesting findings are highlighted.

First, after accounting for differences in a variety of observable characteristics, women's average hourly wage rate is about 84\% - 89\% of the men's average (Table 8, Column 4). Some researchers argue that occupational segregation is a mechanism whereby wage discrimination may occur and that the inclusion of industry and occupation variables may underestimate the degree of wage discrimination. Table 8 shows that the adjusted wage differential is $89.4 \%$ when controls for occupation and industry are included (Specification 4) compared to $86.9 \%$ when these controls are omitted (Specification 3).

Second, despite the long list of productivity related factors, roughly one half to three-quarters of the gender wage gap cannot be explained (Table 9). This finding mirrors the results of other Canadian studies namely, Baker et al. (1995), Gunderson (1998), Christofides and Swidinsky (1994) and Coish and Hale (1995). ${ }^{25}$ This is an interesting finding given that in previous sections it is documented that men and women receive similar returns for a wide range of characteristics. The fact that there are large, unexplained wage differences may be related to the fact that there are large differences in productivity-related factors or skill measures that are not captured by our data set.

Third, differences in the work experience between men and women account for a considerable portion of the wage gap. Gender differences in FYFTE work experience account for, at most, $12 \%$ of the wage gap. Differences in job tenure explain 3\%-5\% of the gender wage gap and differences in parttime status justify $4 \%-9 \%$ of the gender wage gap (Table 9 ).

Fourth, gender differences in major field of study account for at most, 6\% of the gender wage gap but there is considerable variation in the contribution of each major field of study to the gender wage gap (Table 9). About $17 \%{ }^{26}$ of the wage gap can be explained by the fact that men are more likely to graduate from engineering and applied sciences programs and that these degree programs yield high returns. However, the prevalence of women graduating from health science programs and education related fields and the relative high earnings associated with these programs reduces the explained component by $8 \%$.

25 Coish and Hale (1995) use SLID data to examine the gender wage gap, but the population and method selected differs from the current study. First, they select paid workers in January 1993. Second, they include mother tongue, visible minority status, years of schooling and mother's and father's education but omit union status, job tenure and part-time or full-time status. Third, they use the beta coefficients from a pooled regression model of men and women. The current study presumes that the male pay structure would remain intact and compares the wage of comparable men and women.

26 Using controls for FYFTE work experience, major field of study, job tenure, marital status, age of youngest family member, union, part-time, region, CMA / urban size firm size and job duties (Specification 3), the contribution of each major field of study to the gender wage gap is calculated. 
Fifth, gender differences in the opportunity for obtaining supervisory positions and in the performance of certain tasks justifies part of the gender wage gap. Gender differences in supervisory responsibilities and performing related job duties such as deciding work for others and influencing pay and promotion explains, at most, $5 \%$ of the gender wage gap. Work responsibilities such as influencing budget and staffing explains almost $2 \%$ of the gender wage gap (Table 9).

Finally, other wage determining factors have a role in explaining the gender wage gap. The fact that women are clustered into low-wage occupations and industries explains part of the gender wage gap. Differences in occupation and industry explain $9 \%$ and $11 \%$ of the wage gap between men and women (Table 9, Specification 4). Gender differences in union density account for just $0.8 \%$ of the gap. Firm size has a negligible impact on the gender wage gap: roughly $1 \%$ of the gap can be explained by gender differences in firm size.

\section{The impact of using proxies for experience}

Many studies rely on measures such as age or potential experience (= age minus number of years of schooling minus six) as a proxy for actual labour market experience. Baker et al. (1995) note that 'one of the effects of using this proxy is that our analysis will likely attribute to much of the differential between male and female earnings to differences in the return to experience.'

This section attempts to quantify the impact of using proxies for labour market experience on the gender wage gap versus the use of actual labour market experience as measured by the FYFTE work experience variable. The sample used in this section is restricted to paid workers, aged 18 - 64, not enrolled in school full-time, and with known wages, FYFTE experience and number of years of schooling. The resulting sample is 28,303 observations.

Table 3 confirms that these measures tend to overstate the actual labour market experience of women. For instance, the average age of working men and women in 1997 is 39.2 and 39.0 years respectively while the average potential work experience of men and women is 19.5 and 19.1 years. Neither of these measures account for complete withdrawals from the labour market nor for restrictions on the number of hours worked per week or on the number of weeks worked per year due to family-related responsibilities. When an attempt to account for these differences in work history is undertaken, the average number of years of FYFTE work experience is 18.3 years for men and 14.4 years for women.

Separate decomposition models are estimated using the three measures for experience - age, potential work experience and FYFTE work experience. Appendix 3 Table 1 presents a decomposition of the mean differential for each measure while Appendix 3 Table 2 shows the proportion of the gap explained by the variety of experience measures. Two main findings emerge.

First, proxies for experience yield larger adjusted gender wage gaps than when actual experience is used. Appendix 3 Table 1 (Panel 1 and 2) shows that after accounting for differences in the observable characteristics and using age or potential experience as a proxy for work experience, 
women's hourly wage rate is about $81.9 \%$ to $86.9 \%$ of the men's average. Using actual labour market experience, women's average hourly wage rate is $83.5 \%$ to $88.7 \%$ of the men's average (Panel 3 ). ${ }^{27}$

Second, the table indicates that despite the measure of labour market experience used, a significant portion of the differential is due to differences in the returns to the various characteristics. Using age (Appendix 3, Table 3, Panel 1) and potential experience (Panel 2) as a proxy for experience indicates that the unexplained component is 63\%-91\%. When FYFTE is applied, roughly $43 \%-80 \%$ of the gap is unexplained.

Third, the explained portion of the gender wage gap attributable to gender differences in work experience is severely underestimated when proxy measures of experience are used instead of actual labour market experience. Appendix 3 Table 2 shows that at most, $0.6 \%$ of the difference in the hourly wage rates of men and women is attributable to experience when age or potential experience is used as a proxy for experience. Whereas at most $12 \%$ of the gender wage gap is attributable to experience when actual labour market experience is used.

This may be explained as follows. It was noted earlier that there is little gender difference in the mean characteristics of age or of potential experience (Table 3) but there is a significant difference in FYFTE work experience. ${ }^{28}$ Although age and actual work experience are highly correlated, the returns to an additional year of FYFTE experience are greater than the returns to being another year older. ${ }^{29}$ So, when FYFTE experience is used both the difference in means $\left(\bar{X}_{m}-\bar{X}_{f}\right)$ and the difference in returns $\left(\beta_{m}\right)$ produce a greater explained component than when age or potential experience is used.

\section{Discussion}

This paper has attempted to shed new light on an old issue - that of gender wage differentials. One explanation of these wage gaps stresses the difference in wage-determining characteristics. However, attempts to account for the wage differences with productivity-related factors still leave men at a considerable wage advantage. Yet it should be noted that some of the differences in productivity-related factors themselves may reflect discrimination or inequality of opportunity.

Many economists have questioned whether the measures traditionally used in the study of gender wage differentials capture all the productivity-related factors that influence earnings. The fact that men have a wage advantage still leaves many questions unanswered. Namely, are there influences outside the labour market that affect the acquisition of skills? Do we have appropriate data, that is, are we doing a good job at measuring wage-determining skills? Like many other data sets, SLID does not contain information on self-imposed restrictions on work hours or locations. As well, information on the duration

\footnotetext{
27 These results are slightly different than the results presented in Table 8 due to differences in sample selection. In the current sample, respondents for whom number of years of schooling was missing were deleted.

28 Recall that working men are 0.2 years older than working women and that working men have 0.4 more years of potential work experience. The difference is FYFTE work experience is 3.9 years.

29 Men earn about $0.5 \%(0.6 \%-0.7 \%)$ more per year when age (actual labour market experience) is used.
} 
of labour force withdrawals, on the frequency of withdrawals, or on the timing of labour force withdrawals would be a welcome addition to the study of gender wage differentials.

\section{Conclusions}

This article uses data from the Survey of Labour and Income Dynamics (SLID) to investigate the extent to which factors not previously explored in the Canadian context account for wage differences between men and women. Like other studies using standard decomposition techniques, we find that men still enjoy a wage advantage over women: women's average hourly wage rate is about $84 \%-89 \%$ of the men's average. Unlike other studies, controls for work history and job-related responsibilities are used. Gender differences in full-year, full-time work experience explain a substantial proportion of the gender wage gap - roughly $12 \%$. Gender differences in the opportunity to supervise and to perform certain tasks account for about 5\% of the gender wage gap. Yet despite the long list of productivity related factors, roughly one half to three-quarters of the gender wage gap cannot be explained.

Many studies rely on measures such as age or potential experience (= age minus number of years of schooling minus six) as a proxy for actual labour market. Neither of these measures account for complete withdrawals from the labour market nor for restrictions on the number of hours worked per week or on the number of weeks worked per year due to family-related responsibilities. The results show that proxies for experience yield larger adjusted gender wage gaps than when actual experience is used. 


\section{Appendix 1: Notes on econometrics techniques}

This paper uses slightly different econometric techniques than other studies on gender wage gaps. Both female and male observations are used to estimate the following regression:

$$
\ln w_{i}=\alpha_{m}+\alpha_{f} \text { female }+\beta_{m} X_{i}+\beta_{f} X_{i} \text { female }+u_{i}
$$

where $\mathrm{w}$ is the hourly wage for individual $\mathrm{i} ; \alpha$ is the intercept term; $\mathrm{X}$ is a vector of human capital and other wage-determining characteristics; $\beta$ are a vector of estimated regression coefficients showing the return of each characteristic; $m$ denotes males and $f$ denotes females; female $=1$ if individual is a female and 0 otherwise.

The coefficient $\alpha_{\mathrm{f}}$ attached to the dummy variable female is the differential intercept coefficient - it indicates by how much the value of the intercept term for women differs from the intercept term for men.

The coefficient $\beta_{\mathrm{f}}$ is the differential slope coefficient - it indicates by how much the slope coefficient of men's wage equation differs from the slope coefficient of women's wage equation.

Assuming that $\mathrm{E}\left(\mathrm{u}_{\mathrm{i}}\right)=0$, from equation (1) individual regressions for men and women may be derived:

Men

$$
E\left(Y_{i} \mid \text { female }=0, X_{m}\right)=\alpha_{m}+\beta_{m} X_{m}
$$

\section{Women}

$$
E\left(Y_{i} \mid \text { female }=1, X_{f i}\right)=\alpha_{m}+\alpha_{f}+\left(\beta_{m}+\beta_{f}\right) X_{f i}
$$

Simple $t$ tests can be used to test a hypothesis on an individual coefficient. For instance, a t test can be used to test the hypothesis whether the differential intercept term is significantly different from the male intercept term. For differential slope coefficients, the $t$ test can tell us whether the female returns to a characteristic is significantly different from the male returns.

The advantage of this approach is that it allows us to pinpoint the source(s) of the difference in male and female wage equations - for instance, differences due to intercept only (parallel regressions), slope (concurrent regressions) or both slope and intercept (dissimilar regressions).

An F test is used to test a hypothesis on a set of coefficients. That is, the F test is used to test whether a set of slope coefficients are zero simultaneously. For instance, suppose we want to test whether all the female differential slope coefficients are equal to zero simultaneously. The $t$ test may tell us that an individual coefficient is not significantly different from zero but it does not mean that ALL slope coefficients are not significantly different from zero. Oftentimes it is tempting to throw into the model a 
number of variables that may have some explanatory power. The $\mathrm{F}$ test is also useful to test whether or not to include a variable in the regression model. 


\section{Technical Notes on Decomposition}

Multivariate techniques allow the effects of a number of variables to be analyzed simultaneously. This section describes a how multivariate technique known as decomposition is used to analyze wage differentials between men and women. The dependent variable is the log of hourly wage rates. Each coefficient is the percentage change in hourly wage rates associated with a one-unit change in each explanatory variable.

We use the Oaxaca (1973) method of decomposition. Using equations 2 and 3, it can be shown that the average wage differential between men and women can be decomposed into two components:

$$
\bar{W}_{m}-\bar{W}_{f}=\left(\bar{X}_{m}-\bar{X}_{f}\right) \hat{\beta}_{m}+\left(\hat{\beta}_{m}-\hat{\beta}_{f}\right) \bar{X}_{f}
$$

where $\left(\bar{X}_{m}-\bar{X}_{f}\right) \hat{\beta}_{m}$ is the difference in the wage-determining characteristics evaluated at the male pay structure (explained component) and $\left(\hat{\beta}_{m}-\hat{\beta}_{f}\right) \bar{X}_{f}$ is the difference in the returns to these characteristics as well as to differences in the constant term (unexplained component). 
Table 1: Canadian evidence on the gender earnings differential: Results

\begin{tabular}{|c|c|c|c|c|c|c|c|c|c|}
\hline \multirow[t]{2}{*}{ Author / Publication date } & \multirow[t]{2}{*}{ Data } & \multirow[t]{2}{*}{ Year } & \multirow{2}{*}{$\begin{array}{c}\text { Measure of } \\
\text { Earnings } \\
\end{array}$} & \multicolumn{3}{|c|}{ Female:Male Earnings Ratio } & \multicolumn{3}{|c|}{ Results (logs)* } \\
\hline & & & & $\begin{array}{r}\text { Overall a } \\
=\exp (-(A+B)\end{array}$ & $\begin{array}{c}\text { after controll } \\
\text { characteristi } \\
\text { only } \\
=\exp (-\mathrm{B}) \\
\end{array}$ & $\begin{array}{l}\mathrm{r} \text { differences in } \\
\text { returns } \\
\text { only } \\
=\exp (-\mathrm{A}) \\
\end{array}$ & $\begin{array}{c}\text { Raw log } \\
\text { Gender Gap } \\
\text { A+B } \\
\end{array}$ & $\begin{array}{c}\text { Explained } \\
\mathbf{A} \\
(\mathbf{X m}-\mathbf{X f})^{*} \mathbf{B m}\end{array}$ & $\begin{array}{c}\text { Unexplained } \\
\text { B } \\
\mathrm{n}(\mathrm{Bm}-\mathrm{Bf}) * \mathbf{X f} \\
\end{array}$ \\
\hline \multirow[t]{4}{*}{ Gunderson (1998) } & Census & 1970 & annual & 0.626 & 0.739 & 0.846 & $\begin{array}{l}0.469 \\
100 \%\end{array}$ & $\begin{array}{l}0.166 \\
35.4 \%\end{array}$ & $\begin{array}{l}0.302 \\
64.4 \%\end{array}$ \\
\hline & & 1980 & annual & 0.668 & 0.765 & 0.874 & $\begin{array}{l}0.403 \\
100 \%\end{array}$ & $\begin{array}{l}0.135 \\
33.5 \%\end{array}$ & $\begin{array}{l}0.268 \\
66.5 \%\end{array}$ \\
\hline & & 1990 & annual & 0.721 & 0.795 & 0.908 & $\begin{array}{l}0.326 \\
100 \%\end{array}$ & $\begin{array}{l}0.096 \\
29.4 \%\end{array}$ & $\begin{array}{c}0.23 \\
70.6 \%\end{array}$ \\
\hline & & 1990 & weekly & 0.616 & 0.773 & 0.796 & 0.485 & 0.228 & 0.257 \\
\hline \multirow[t]{8}{*}{ Baker et al. (1995) } & Census & $-\overline{1970}$ & annual & 0.602 & 0.688 & $0 . \overline{875}$ & $\begin{array}{l}100 \% \\
0.508\end{array}$ & $\begin{array}{c}-47.0 \% \\
0.134\end{array}$ & $--53.0 \%=$ \\
\hline & & 1980 & annual & 0.644 & 0.725 & 0.889 & $\begin{array}{l}100 \% \\
0.439 \\
100 \%\end{array}$ & $\begin{array}{l}26.4 \% \\
0.118 \\
26.9 \%\end{array}$ & $\begin{array}{l}73.8 \% \\
0.321 \\
73.1 \%\end{array}$ \\
\hline & & 1985 & annual & 0.656 & 0.727 & 0.900 & $\begin{array}{l}0.422 \\
100 \%\end{array}$ & $\begin{array}{l}0.103 \\
24.4 \%\end{array}$ & $\begin{array}{l}0.317 \\
75.1 \%\end{array}$ \\
\hline & SCF & 1986 & annual & 0.643 & 0.705 & 0.912 & $\begin{array}{l}0.441 \\
100 \%\end{array}$ & $\begin{array}{l}0.092 \\
20.9 \%\end{array}$ & $\begin{array}{l}0.349 \\
79.1 \%\end{array}$ \\
\hline & & 1990 & annual & 0.669 & 0.715 & 0.938 & $\begin{array}{l}0.402 \\
100 \%\end{array}$ & $\begin{array}{l}0.066 \\
16.4 \%\end{array}$ & $\begin{array}{r}0.338 \\
84.1 \%\end{array}$ \\
\hline & Census & $70 / 80$ & & \multirow{3}{*}{\multicolumn{3}{|c|}{$\begin{array}{l}\text { refer to text for calculation of of change in the } \\
\text { earnings gap between two periods }\end{array}$}} & $\begin{array}{c}-0.07 \\
100.0 \%\end{array}$ & $\begin{array}{c}0.01 \\
-14.3 \%\end{array}$ & $\begin{array}{c}-0.08 \\
114.3 \%\end{array}$ \\
\hline & Census & $80 / 85$ & & & & & $\begin{array}{l}-0.017 \\
100.0 \%\end{array}$ & $\begin{array}{l}-0.011 \\
64.7 \%\end{array}$ & $\begin{array}{l}-0.006 \\
35.3 \%\end{array}$ \\
\hline & SCF & $85 / 90$ & & & & & -0.039 & -0.003 & -0.033 \\
\hline Coish \& Hale (95) & SLID & $-\overline{1993}$ & hourly & 0.779 & 0.803 & 0.97 & $\begin{array}{c}-\overline{-25} \\
100 \%\end{array}$ & $\begin{array}{c}0.03 \\
12.0 \%\end{array}$ & $\begin{array}{c}-84.6 \% \\
0.220 \\
88.0 \%\end{array}$ \\
\hline
\end{tabular}

Note: * To convert the reported differences in mean log earnings to ratios of female to male earnings, calculate ratio $=\exp (-$ difference). For instance, in the Baker et al. paper, the ratio of female to male earnings increases from 0.60 to 0.66 between $1970-1985$.

LMAS: Labour Market Activity Survey; SLID: Survey of Labour and Income Dynamics; SCF: Survey of Consumer Finances; NGS: National Graduate Surve

These studies decompose the average wage differential between females and males into two components: differences in the average wage-determining characteristics $(\mathrm{Xm}-\mathrm{Xf})$ evaluated according to the male returns Bm (Explained) and differences in the pay men and women receive (Bm-Bf) evaluated at the female endowments $\mathrm{X}$ 
Table 2: Earnings ratios based on data from the Survey of Consumer Finances, 1997

\begin{tabular}{|c|c|c|c|c|c|c|c|c|c|c|c|}
\hline \multirow[t]{2}{*}{ Characteristics } & \multicolumn{5}{|c|}{ FYFT workers } & \multicolumn{3}{|c|}{ Other workers } & \multicolumn{3}{|c|}{ All earners } \\
\hline & & Men & & Women & $\begin{array}{c}\text { Earnings } \\
\text { ratio }\end{array}$ & Men & Women & $\begin{array}{c}\text { Earnings } \\
\text { Ratios } \\
\end{array}$ & Men & Women & $\begin{array}{c}\text { Earnings } \\
\text { Ratio } \\
\end{array}$ \\
\hline Overall & $\$$ & 42,626 & $\$$ & 30,915 & $72.5 \%$ & $\$ 13,821$ & $\$ 10,870$ & $78.6 \%$ & $\$ 33,185$ & $\$ 21,167$ & $63.8 \%$ \\
\hline \multicolumn{12}{|l|}{ Age } \\
\hline $15-24$ & & na & & na & 80.8 & na & na & na & na & na & na \\
\hline $25-34$ & & 37,810 & & 28,833 & 76.3 & 16,368 & 12,139 & 74.2 & 31,701 & 21,786 & 68.7 \\
\hline $35-44$ & & 44,819 & & 32,916 & 73.4 & 19,321 & 13,436 & 69.5 & 39,828 & 25,262 & 63.4 \\
\hline $44-54$ & & 47,957 & & 33,452 & 69.8 & 20,917 & 13,688 & 65.4 & 43,228 & 26,385 & 61.0 \\
\hline $55-64$ & & 45,578 & & 29,017 & 63.7 & 18,953 & 12,873 & 67.9 & 37,566 & 20,540 & 54.7 \\
\hline \multicolumn{12}{|l|}{ Education } \\
\hline Less than high school & & 30,731 & & 21,403 & 69.6 & 12,641 & 8,476 & 67.1 & 23,109 & 14,107 & 61.0 \\
\hline Some high school & & 35,367 & & 22,846 & 64.6 & 10,251 & 6,638 & 64.8 & 23,096 & 12,292 & 53.2 \\
\hline High school graduate & & 37,705 & & 27,525 & 73.0 & 14,179 & 10,570 & 74.5 & 30,796 & 19,551 & 63.5 \\
\hline Some post secondary & & 37,812 & & 28,360 & 75.0 & 10,052 & 8,263 & 82.2 & 24,298 & 16,405 & 67.5 \\
\hline Completed post secondary & & 41,868 & & 29,539 & 70.6 & 16,465 & 12,710 & 77.2 & 35,197 & 21,990 & 62.5 \\
\hline University & & 57,930 & & 42,661 & 73.6 & 20,821 & 16,689 & 80.2 & 50,099 & 33,344 & 66.6 \\
\hline \multicolumn{12}{|l|}{ Marital status } \\
\hline Single & & 33,451 & & 30,720 & 91.8 & 8,927 & 7,842 & 0.9 & 19,591 & 16,208 & 82.7 \\
\hline Married & & 45,102 & & 30,424 & 67.5 & 19,407 & 12,263 & 0.6 & 39,494 & 22,383 & 56.7 \\
\hline Other & & 42,300 & & 33,950 & 80.3 & 17,699 & 13,792 & 0.8 & 35,334 & 26,367 & 74.6 \\
\hline \multicolumn{12}{|l|}{ Region } \\
\hline Atlantic provinces & & 36,549 & & 25,928 & 70.9 & 11,735 & 7,838 & 66.8 & 25,215 & 15,797 & 62.6 \\
\hline Quebec & & 39,100 & & 29,209 & 74.7 & 14,521 & 10,927 & 75.2 & 31,018 & 20,401 & 65.8 \\
\hline Ontario & & 45,841 & & 33,494 & 73.1 & 13,105 & 10,833 & 82.7 & 36,101 & 23,274 & 64.5 \\
\hline Prairie provinces & & 40,534 & & 27,415 & 67.6 & 13,170 & 10,830 & 82.2 & 31,953 & 18,908 & 59.2 \\
\hline British Columbia & & 45,050 & & 32,849 & 72.9 & 16,720 & 12,791 & 76.5 & 34,876 & 22,417 & 64.3 \\
\hline \multicolumn{12}{|l|}{ Job Tenure } \\
\hline Less than 1 year & & 36,231 & & 26,715 & 73.7 & 12,410 & 8,975 & 72.3 & 22,175 & 14,064 & 63.4 \\
\hline $1-5$ years & & 37,543 & & 27,443 & 73.1 & 15,670 & 12,202 & 77.9 & 32,505 & 21,088 & 64.9 \\
\hline $6-10$ years & & 43,480 & & 31,641 & 72.8 & 19,380 & 16,318 & 84.2 & 40,886 & 27,462 & 67.2 \\
\hline $11-20$ years & & 47,190 & & 34,230 & 72.5 & 31,147 & 18,734 & 60.1 & 46,039 & 30,269 & 65.7 \\
\hline $20+$ vears & & 48.720 & & 36.414 & 74.7 & 26.573 & 18.639 & 70.1 & 47.225 & 33.035 & 70.0 \\
\hline
\end{tabular}

Source: Survey of Consumer Finances, 1997, Statistics Canada, Catalogue 13-217-XPB, Text Table 1, Tables 2, 4, 6, 7, 9

Note: na not available 
Table 3: Gender differences in work history, 1997

\begin{tabular}{|c|c|c|c|}
\hline & Men & & Women \\
\hline Average age & 39.2 & & 39.0 \\
\hline Average number of years of schooling & 13.6 & & 13.8 \\
\hline $\begin{array}{l}\text { Average number of potential years of work } \\
\text { experience ( = age - years of schooling - } 6)\end{array}$ & 19.5 & & 19.1 \\
\hline $\begin{array}{l}\text { Average number of years of } \\
\text { full-year, full-time work experience (FYFTE) }\end{array}$ & 18.3 & & 14.4 \\
\hline $\begin{array}{l}\text { Proportion of potential years of work experience } \\
\text { spent working FYFTE }\end{array}$ & $93.8 \%$ & & $75.4 \%$ \\
\hline $\begin{array}{l}\text { Female:male ratio in FYFTE work experience } \\
\text { (average FYFTE women / average FYFTE men) }\end{array}$ & & $78.7 \%$ & \\
\hline $\begin{array}{l}\text { Average job tenure with present } \\
\text { employer (in years) }\end{array}$ & 9.7 & & 8.4 \\
\hline Proportion of hours worked part-time & $2.7 \%$ & & $13.8 \%$ \\
\hline $\begin{array}{l}\text { Among hours worked part-time, percent citing } \\
\text {... reason for part-time work is family-related } \\
\text { responsibilities }\end{array}$ & .. & & $17.5 \%$ \\
\hline ... voluntarily employed part-time & $61.9 \%$ & & $62.3 \%$ \\
\hline Number of observations & 14.604 & & 13.699 \\
\hline
\end{tabular}

Source: Survey of Labour and Income Dynamics, 1997

Note: The sample used in this table is restricted to paid workers, aged 18-64, not enrolled in school full-time, and with known hourly wage rates, FYFT experience and number of years of schooling.

The number of observations are 28,303.

.. Number too small to report. 
Table 4: Gender differences in work reponsibilities, 1997

\begin{tabular}{|c|c|c|c|c|c|}
\hline & \multicolumn{2}{|c|}{ Proportion of work hours } & \multicolumn{3}{|c|}{ Hourly wage rate } \\
\hline & Men & Women & Men & Women & Ratio \\
\hline Responsible for budget or staffing & 21.7 & 15.7 & $\$ 23.21$ & $\$ 18.76$ & $80.8 \%$ \\
\hline Not a supervisor & 64.3 & 74.9 & 17.29 & 14.30 & $82.7 \%$ \\
\hline Supervisor and & 35.2 & 24.8 & 21.62 & 17.58 & $81.3 \%$ \\
\hline $\begin{array}{c}\text {... influence pay / promotion OR } \\
\text { decide work for others }\end{array}$ & 14.1 & 11.6 & 20.48 & 16.84 & $82.2 \%$ \\
\hline $\begin{array}{l}\text {... influence pay / promotion AND } \\
\text { decide work for others }\end{array}$ & 16.1 & 9.2 & 23.41 & 19.32 & $82.5 \%$ \\
\hline $\begin{array}{l}\text {... NEITHER influence pay / promotion NOR } \\
\text { decide work for others }\end{array}$ & 5.0 & 4.0 & 19.18 & 15.84 & $82.6 \%$ \\
\hline
\end{tabular}

Source: Survey of Labour and Income Dynamics, 1997 
Table 5: Gender differentials in education level and major field of study, 1997

\begin{tabular}{|c|c|c|c|c|c|c|c|}
\hline \multirow[b]{3}{*}{ Overall } & \multicolumn{3}{|c|}{ All workers: Hourly wage rates } & \multicolumn{2}{|c|}{ Percentage distribution } & \multicolumn{2}{|c|}{$\begin{array}{c}\text { Gender } \\
\text { Composition } \\
\end{array}$} \\
\hline & Men & Women & \multirow{2}{*}{$\begin{array}{l}\text { Ratio } \\
80.3 \%\end{array}$} & \multirow{2}{*}{$\begin{array}{l}\text { Men } \\
100.0\end{array}$} & \multirow{2}{*}{$\begin{array}{r}\text { Women } \\
100.0\end{array}$} & \multirow{2}{*}{$\begin{array}{l}\text { Men } \\
57.0\end{array}$} & \multirow{2}{*}{$\begin{array}{r}\text { Women } \\
43.0\end{array}$} \\
\hline & $\$ \quad 18.84$ & $\$ \quad 15.12$ & & & & & \\
\hline \multicolumn{8}{|l|}{ Education and major field of study } \\
\hline \multirow[t]{2}{*}{ Less than high school } & 15.49 & 10.71 & 69.1 & & & & 33.9 \\
\hline & & & & 17.2 & 11.7 & 66.1 & \\
\hline \multirow[t]{2}{*}{ High School } & 16.64 & 13.04 & 78.4 & & & & 45.4 \\
\hline & & & & 17.9 & 19.7 & 54.6 & \\
\hline \multirow[t]{2}{*}{ Incomplete post secondary } & 17.20 & 13.85 & 80.5 & & & & 40.0 \\
\hline & & & & 13.4 & 11.8 & 60.0 & \\
\hline Post secondary diploma or certificate & 19.13 & 15.19 & 79.4 & 33.9 & 38.1 & 54.1 & 45.9 \\
\hline \multirow[t]{2}{*}{ Education, recreational counselling } & 17.08 & 14.65 & 85.8 & & & & 78.9 \\
\hline & & & & 0.6 & 3.2 & 21.1 & \\
\hline \multirow{2}{*}{ Fine and applied arts } & 16.43 & 12.61 & 76.7 & & & & 64.1 \\
\hline & & & & 1.0 & 2.7 & 35.9 & \\
\hline Humanities and related fields & 17.41 & 14.95 & 85.9 & & & & 54.3 \\
\hline & & & & 1.0 & 1.8 & 45.7 & \\
\hline Social science and related fields & 17.89 & 14.45 & 80.8 & & & & 50.9 \\
\hline & & & & 1.4 & 2.0 & 49.1 & \\
\hline Commerce management and bus. admin. & 19.56 & 14.80 & 75.7 & & & & 68.7 \\
\hline & & & & 5.1 & 13.8 & 31.3 & \\
\hline Agricultural, biological science & 14.44 & 12.97 & 89.8 & & & & 38.6 \\
\hline & & & & 1.4 & 1.3 & 61.4 & \\
\hline Engineering and applied science trades & 19.75 & 15.65 & 79.2 & & & & 8.7 \\
\hline & & & & 19.8 & 2.5 & 91.3 & \\
\hline Health professions, science and & 18.05 & 17.67 & 97.9 & & & & 86.3 \\
\hline technology & & & & 0.9 & 8.0 & 13.7 & \\
\hline Mathematics & 21.97 & 16.28 & 74.1 & & & & 46.6 \\
\hline & & & & 1.0 & 1.0 & 53.4 & \\
\hline No specialization & 17.41 & 13.80 & 79.3 & & & & 54.1 \\
\hline & & & & 1.2 & 1.9 & 45.9 & \\
\hline University - bachelor degree & 24.34 & 20.57 & 84.5 & 13.0 & 15.4 & 52.8 & 47.2 \\
\hline Education, recreational counselling & 22.36 & 19.98 & 89.4 & & & & 66.5 \\
\hline & & & & 1.4 & 3.6 & 33.5 & \\
\hline Fine and applied arts & .. & 19.11 & na & .. & & & 66.4 \\
\hline & & & & & 0.4 & 33.6 & \\
\hline Humanities and related fields & 23.19 & 20.01 & 86.3 & & & & 57.8 \\
\hline & & & & 1.3 & 2.3 & 42.2 & \\
\hline Social science and related fields & 22.66 & 20.31 & 89.6 & & & & 50.0 \\
\hline & & & & 2.2 & 2.8 & 50.0 & \\
\hline Commerce management and bus. admin. & 24.91 & 21.29 & 85.5 & & & & 39.6 \\
\hline & & & & 2.9 & 2.1 & 60.4 & \\
\hline Agricultural, biological science & 22.68 & 18.08 & 79.7 & & & & 54.5 \\
\hline & & & & 0.5 & 0.7 & 45.5 & \\
\hline Engineering and applied science trades & 26.84 & .. & na & & .. & & 7.3 \\
\hline & & & & 2.4 & & 92.7 & \\
\hline Health professions, science and & na & 24.05 & na & .. & & & 78.2 \\
\hline technology & & & & & 1.3 & 21.8 & \\
\hline Mathematics & 24.80 & 22.23 & 89.6 & & & & 30.7 \\
\hline & & & & 1.7 & 0.8 & 69.3 & \\
\hline No specialization & .. & .. & na & .. & .. & .. & . \\
\hline Greater than university bachelor degree & 27.77 & 22.55 & 81.2 & 4.1 & 2.9 & 54.5 & 45.5 \\
\hline Education, recreational counselling & 27.37 & 23.35 & 85.3 & & & & 59.4 \\
\hline & & & & 0.5 & 0.5 & 40.6 & \\
\hline Fine and applied arts & .. & .. & na & .. & .. &.. & .. \\
\hline Humanities and related fields & 21.27 & 18.32 & 86.1 & .. & & .. & 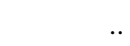 \\
\hline
\end{tabular}




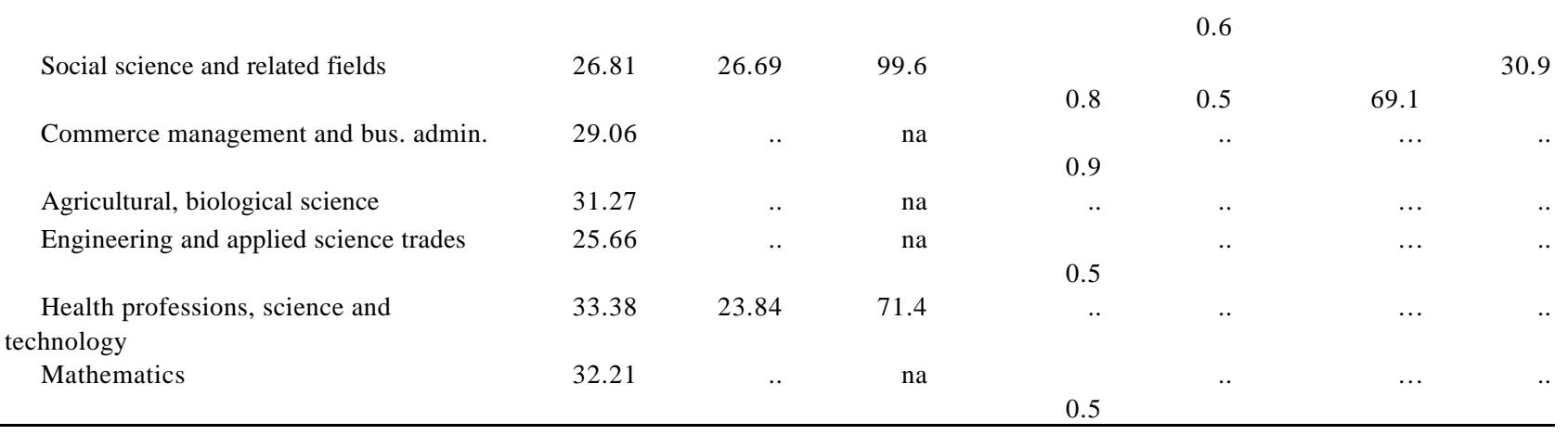

Source: Survey of Labour and Income Dynamics, 1997

Note: .. Number too small to report

... number suppressed for confidentiality reasons 
Table 6: Gender differentials in raw average compensation by demographic characteristics, 1997

\begin{tabular}{|c|c|c|c|c|c|c|c|c|c|}
\hline \multirow{3}{*}{$\begin{array}{l}\text { Characteristic } \\
\text { Overall }\end{array}$} & \multicolumn{5}{|c|}{ All workers: Hourly wage rates } & \multicolumn{4}{|c|}{ FYFT workers: Annual Earnings } \\
\hline & \multicolumn{2}{|c|}{ Men } & \multicolumn{2}{|c|}{ Women } & \multirow{2}{*}{$\begin{array}{r}\text { Ratio* } \\
80.3 \%\end{array}$} & \multicolumn{2}{|c|}{ Men } & Women & \multirow{2}{*}{$\begin{array}{l}\text { Ratio } \\
68.3 \%\end{array}$} \\
\hline & $\$$ & 18.83 & $\$$ & 15.12 & & $\$$ & 46,108 & $\$ 31,506$ & \\
\hline \multicolumn{10}{|l|}{ Age group } \\
\hline $18-24$ & & 11.00 & & 9.36 & 85.1 & & 22,749 & 17,178 & 75.5 \\
\hline $25-34$ & & 16.71 & & 14.39 & 86.1 & & 40,527 & 28,617 & 70.6 \\
\hline $35-44$ & & 20.25 & & 16.38 & 80.9 & & 47,730 & 34,414 & 72.1 \\
\hline $45-54$ & & 21.68 & & 16.34 & 75.4 & & 54,449 & 34,566 & 63.5 \\
\hline $55-64$ & & 19.66 & & 14.22 & 72.3 & & 49,232 & 28,988 & 58.9 \\
\hline \multicolumn{10}{|l|}{ Marital status } \\
\hline Married or common-law & & 20.09 & & 15.45 & 76.9 & & 49,629 & 31,736 & 63.9 \\
\hline Single, never married & & 14.53 & & 14.00 & 96.4 & & 32,986 & 30,432 & 92.3 \\
\hline Other & & 18.67 & & 15.14 & 81.1 & & 42,499 & 31,959 & 75.2 \\
\hline \multicolumn{10}{|c|}{ Age of youngest family member } \\
\hline No children / or children $19+$ & & 17.83 & & 15.16 & 85.0 & & 43,259 & 32,161 & 74.3 \\
\hline $0-4$ years & & 19.49 & & 15.55 & 79.8 & & 47,052 & 29,382 & 62.4 \\
\hline $5-9$ years & & 19.97 & & 15.38 & 77.0 & & 50,206 & 32,799 & 65.3 \\
\hline $10-14$ years & & 20.21 & & 15.04 & 74.4 & & 50,477 & 31,654 & 62.7 \\
\hline $15-19$ years & & 19.28 & & 14.22 & 73.8 & & 46,596 & 30,048 & 64.5 \\
\hline \multicolumn{10}{|l|}{ FYFT work experience } \\
\hline $0-2$ years & & 11.28 & & 10.77 & 95.5 & & 21,892 & 20,504 & 93.7 \\
\hline $3-5$ years & & 14.33 & & 12.47 & 87.0 & & 32,234 & 24,967 & 77.5 \\
\hline $6-9$ years & & 16.38 & & 13.96 & 85.2 & & 37,280 & 27,551 & 73.9 \\
\hline 10-19 years & & 19.32 & & 15.87 & 82.1 & & 46,749 & 32,492 & 69.5 \\
\hline 20-29 years & & 21.19 & & 17.36 & 81.9 & & 52,604 & 36,116 & 68.7 \\
\hline 30-39 years & & 21.30 & & 16.67 & 78.3 & & 53,098 & 35,191 & 66.3 \\
\hline $40+$ years & & 17.92 & & 15.39 & 85.9 & & 41,248 & 31,935 & 77.4 \\
\hline \multicolumn{10}{|l|}{ Region } \\
\hline Atlantic & & 15.51 & & 12.58 & 81.1 & & 37,422 & 26,855 & 71.8 \\
\hline Quebec & & 18.07 & & 14.53 & 80.4 & & 41,887 & 28,414 & 67.8 \\
\hline Ontario & & 20.00 & & 16.23 & 81.2 & & 50,808 & 35,076 & 69.0 \\
\hline Prairies & & 16.66 & & 13.24 & 79.5 & & 40,857 & 27,037 & 66.2 \\
\hline Alberta & & 18.77 & & 14.33 & 76.3 & & 47,375 & 30,727 & 64.9 \\
\hline British Columbia & & 19.92 & & 16.00 & 80.3 & & 46,077 & 31,884 & 69.2 \\
\hline \multicolumn{10}{|l|}{ CMA and urban size class } \\
\hline Rural & & 17.62 & & 14.09 & 80.0 & & 41,577 & 29,886 & 71.9 \\
\hline Less than 25,000 & & 18.00 & & 14.04 & 78.0 & & 44,364 & 28,764 & 64.8 \\
\hline $25,000-99,999$ & & 18.79 & & 14.50 & 77.2 & & 44,280 & 29,188 & 65.9 \\
\hline $100,000-249,999$ & & 19.58 & & 15.05 & 76.9 & & 47,066 & 31,791 & 67.5 \\
\hline $250,000-999,999$ & & 19.20 & & 15.36 & 80.0 & & 46,528 & 32,047 & 68.9 \\
\hline Montreal & & 19.14 & & 14.79 & 77.3 & & 44,788 & 29,212 & 65.2 \\
\hline Toronto & & 20.31 & & 17.21 & 84.7 & & 56,595 & 37,652 & 66.5 \\
\hline Vancouver & & 19.59 & & 16.90 & 86.3 & & 45,483 & 34,106 & 75.0 \\
\hline Number of observations & & 14,839 & & 13,902 & 28,741 & & 9,020 & 6,667 & 15,687 \\
\hline
\end{tabular}

Source: Survey of Labour and Income Dynamics, 1997

* A regression of log hourly wages on a constant and a dummy variable for men indicate that the ratios reported are statistically significant at the $5 \%$ level. 
Table 7: Gender pay differentials by various work-related characteristics, 1997

\begin{tabular}{|c|c|c|c|c|c|c|c|c|c|c|}
\hline \multirow[b]{2}{*}{ Characteristic } & \multicolumn{5}{|c|}{ All workers: Hourly wage rates } & \multicolumn{5}{|c|}{ FYFT workers: Annual Earnnings } \\
\hline & \multicolumn{2}{|r|}{ Men } & \multicolumn{2}{|c|}{ Women } & \multirow{2}{*}{$\begin{array}{l}\text { Ratio* } \\
80.3 \%\end{array}$} & \multicolumn{2}{|r|}{ Men } & \multicolumn{2}{|c|}{ Women } & \multirow{2}{*}{$\begin{array}{l}\text { Ratio } \\
688.3 \%\end{array}$} \\
\hline Overall & $\$$ & 18.84 & $\$$ & 15.12 & & $\$$ & 46,108 & $\$$ & 31,506 & \\
\hline \multicolumn{11}{|l|}{ Industry } \\
\hline Agriculture/Fishing & & 12.44 & & 9.65 & 77.6 & & 28,687 & & 19,217 & 67.0 \\
\hline Forestry/mining & & 21.31 & & 20.00 & 93.9 & & 56,420 & & 47,556 & 84.3 \\
\hline Construction & & 18.38 & & 13.45 & 73.2 & & 40,686 & & 28,310 & 69.6 \\
\hline Manufacturing & & 19.13 & & 13.92 & 72.8 & & 47,290 & & 30,124 & 63.7 \\
\hline Business services & & 18.70 & & 17.24 & 92.2 & & 46,555 & & 35,559 & 76.4 \\
\hline Distributive services & & 21.92 & & 15.62 & 71.3 & & 62,098 & & 32,626 & 52.5 \\
\hline Consumer services & & 13.81 & & 10.27 & 74.4 & & 33,449 & & 21,699 & 64.9 \\
\hline Public services & & 21.64 & & 17.97 & 83.0 & & 46,825 & & 35,398 & 75.6 \\
\hline \multicolumn{11}{|l|}{ Status } \\
\hline Full-time & & 18.94 & & 15.32 & 80.9 & & - & & - & - \\
\hline Part-time & & 15.02 & & 13.87 & 92.3 & & - & & - & - \\
\hline \multicolumn{11}{|l|}{ Union } \\
\hline Covered by CBA / union member & & 20.63 & & 17.86 & 86.6 & & 46,276 & & 35,229 & 76.1 \\
\hline Not unionized & & 17.80 & & 13.61 & 76.5 & & 46,036 & & 29,217 & 63.5 \\
\hline \multicolumn{11}{|l|}{ Job tenure } \\
\hline Less than 1 year & & 14.17 & & 11.22 & 79.2 & & 33,824 & & 24,438 & 72.3 \\
\hline $1-5$ years & & 16.37 & & 13.16 & 80.4 & & 39,395 & & 26,733 & 67.9 \\
\hline $6-10$ years & & 19.00 & & 15.71 & 82.7 & & 43,793 & & 31,303 & 71.5 \\
\hline $11-19$ years & & 21.54 & & 17.49 & 81.2 & & 50,211 & & 35,343 & 70.4 \\
\hline $20+$ years & & 22.92 & & 18.99 & 82.9 & & 56,984 & & 38,574 & 67.7 \\
\hline \multicolumn{11}{|l|}{ Occupation } \\
\hline Professional / managers & & 23.94 & & 18.89 & 78.9 & & 65,088 & & 39,404 & 60.5 \\
\hline Natural or social science & & 23.72 & & 19.70 & 83.1 & & 52,041 & & 39,727 & 76.3 \\
\hline Clerical & & 15.41 & & 13.36 & 86.7 & & 33,884 & & 26,680 & 78.7 \\
\hline Sales & & 17.85 & & 11.86 & 66.4 & & 48,581 & & 25,909 & 53.3 \\
\hline Services & & 14.74 & & 10.03 & 68.0 & & 34,279 & & 20,419 & 59.6 \\
\hline Primary, processing, machinery & & 17.34 & & 11.43 & 65.9 & & 41,967 & & 24,812 & 59.1 \\
\hline Construction & & 18.43 & & 12.82 & 69.6 & & 40,296 & & 29,608 & 73.5 \\
\hline Other & & 16.84 & & 14.60 & 86.7 & & 39,572 & & 30,168 & 76.2 \\
\hline \multicolumn{11}{|l|}{ Firm size } \\
\hline Less than 20 employees & & 14.46 & & 11.99 & 82.9 & & 32,261 & & 24,723 & 76.6 \\
\hline 20 - 99 employees & & 17.11 & & 13.97 & 81.6 & & 41,623 & & 28,674 & 68.9 \\
\hline 100-499 employees & & 19.55 & & 15.77 & 80.7 & & 49,273 & & 32,017 & 65.0 \\
\hline 500 + employees & & 21.55 & & 17.08 & 79.3 & & 52,164 & & 35,313 & 67.7 \\
\hline Number of observations & & 14.839 & & 13.902 & 28.741 & & 9.020 & & 6,667 & 15.687 \\
\hline
\end{tabular}

Source: Survey of Labour and Income Dynamics, 1997

* A regression of log hourly wages on a constant and a dummy variable for men indicate that the ratios reported are statistically significant at the $5 \%$ level, except for the gap reported in forestry and mining. 
Table 8: Decomposition of the gender earnings differential

\begin{tabular}{|c|c|c|c|c|}
\hline & $\begin{array}{l}\text { Unadjusted } \\
\text { Differential } \\
\text { (in logs) } \\
\\
\text { (1) } \\
\end{array}$ & $\begin{array}{c}\text { Explained } \\
\text { (differences due to } \\
\text { wage-determining factors) } \\
=(\mathrm{Xm}-\mathrm{Xf}) \mathrm{Bm} \\
(2)\end{array}$ & $\begin{array}{c}\text { Unexplained } \\
\text { (differences due to returns to } \\
\text { wage-determining factors) } \\
=(\mathrm{Bm}-\mathrm{Bf}) \mathrm{Xf} \\
\text { (3) }\end{array}$ & $\begin{array}{c}\begin{array}{c}\text { Adjusted } \\
\text { differential }\end{array} \\
=\exp (-(\mathrm{Bm}-\mathrm{Bf}) \mathrm{Xf}) \\
(4) \\
\end{array}$ \\
\hline Specification (1) & 0.221 & 0.047 & 0.173 & $84.1 \%$ \\
\hline Specification (2) & 0.221 & 0.068 & 0.153 & $85.8 \%$ \\
\hline Specification (3) & 0.221 & 0.081 & 0.140 & $86.9 \%$ \\
\hline Specification (4) & 0.221 & 0.109 & 0.112 & $89.4 \%$ \\
\hline
\end{tabular}

Note: Adjusted differential refers to the female's earnings as a percentage of male earnings after controlling for differences in observable characteristics. To convert our reported differences in mean log earnings to ratios of female to male earnings the following calculation is performed: ratio $=\exp (-$ unexplained). For example, female average earnings are about $84.1 \%$ of the male ratio after for accounting for differences in FYFTE work experience, major field of study, tenure, marital status and age of youngest family member (Specification 1). 
Table 9: Accounting for the gender wage gap, 1997

Fraction of gender wage gap explained by ...

\begin{tabular}{lrrrr} 
& Specification & & & \\
Factors explaining the gap & $\mathbf{1}$ & $\mathbf{2}$ & $\mathbf{3}$ & $\mathbf{4}$ \\
\hline & & & & \\
Education level*major field of study & 3.2 & 4.8 & 5.8 & 4.5 \\
FYFTE experience & 11.5 & 11.5 & 10.4 & 10.1 \\
Tenure & 5.0 & 3.1 & 2.9 & 2.8 \\
Age of youngest family member & 0.9 & 0.7 & 0.7 & 0.7 \\
Marital status & 1.0 & 0.7 & 0.8 & 0.8 \\
Part-time status & & 8.5 & 7.1 & 3.6 \\
Region & & 0.0 & 0.0 & 0.0 \\
CMA / urban size & -0.3 & -0.3 & -0.6 \\
Union status & & 0.6 & 0.9 & 0.8 \\
Firm size & & 1.1 & 1.1 & 0.9 \\
Duties & & & 5.3 & 4.3 \\
Influence budget and staffing decisions & & & 2.1 & 1.3 \\
Industry & & & & 11.2 \\
Occupation & & & & 8.6 \\
\hline & & & & \\
Total explained & & & & \\
Total unexplained & & & & \\
\hline Total & 78.4 & 69.3 & 63.2 & 51.0 \\
\hline
\end{tabular}


Appendix 2, Table 1: Regression results: significant female interactions (5\% level of significance)

Dependent variable: Log hourly wage rates

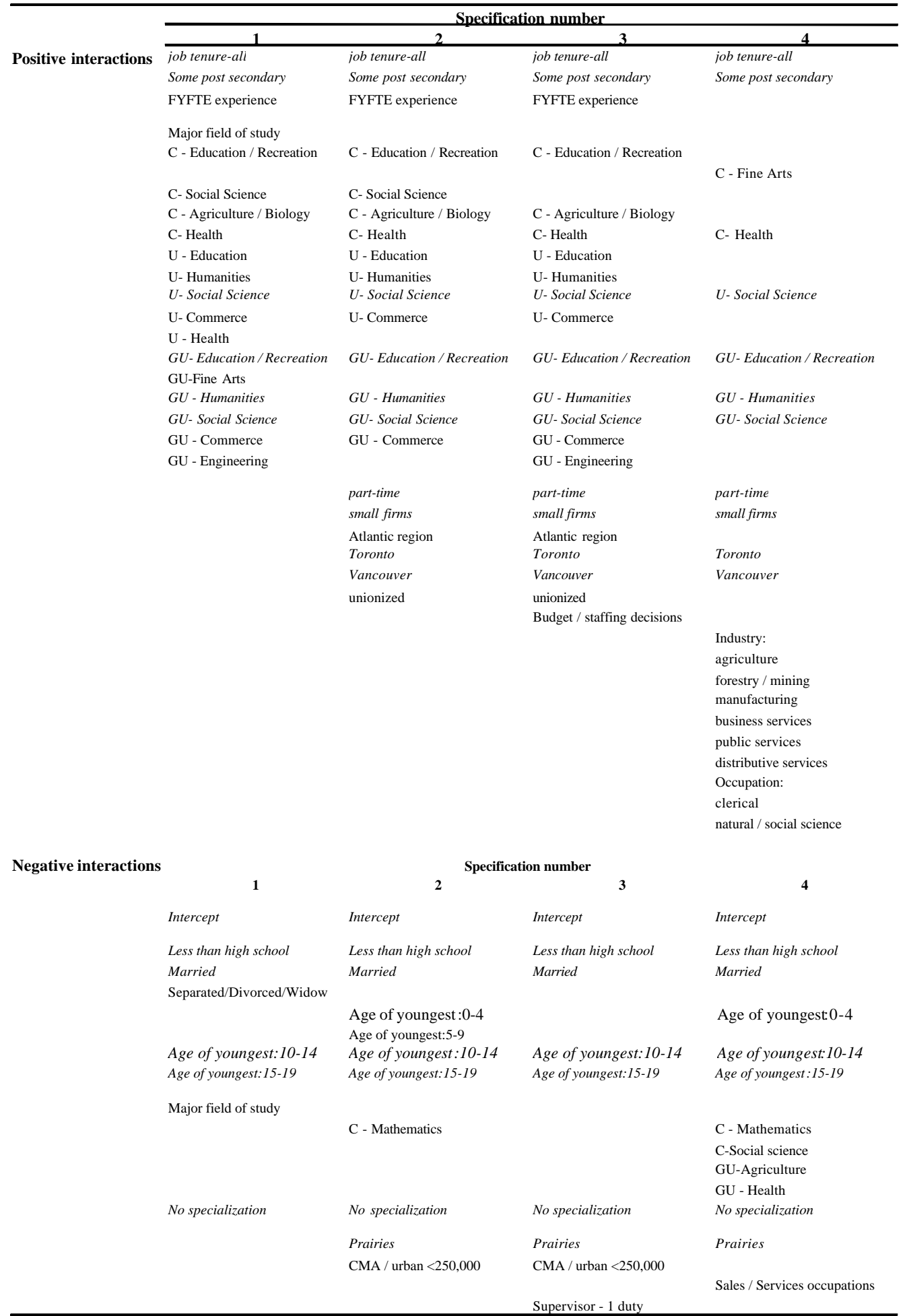

Note: Positive (negative) interactions denote characteristics for which women are paid relatively better (worse) than men

Characteristics in italics are interactions that are siginificant at the $5 \%$ level for all specifications. 
Appendix 3, Table 1: Decomposition of the gender wage gap using age, potential experience and actual experience

Panel 1: Using age as a proxy for

\begin{tabular}{lcccc} 
& $\begin{array}{c}\text { Unadjusted } \\
\text { Differential } \\
\text { (in logs) }\end{array}$ & $\begin{array}{c}\text { Explained } \\
\text { (differences due to } \\
\text { wage-determining factors) } \\
=(\text { Xm-Xf)Bm } \\
(1)\end{array}$ & $\begin{array}{c}\text { Unexplained } \\
\text { (differences due to returns to } \\
\text { wage-determining factors) } \\
=(\mathrm{Bm}-\mathrm{Bf}) \mathrm{Xf} \\
(3)\end{array}$ & $\begin{array}{c}\text { Adjusted } \\
\text { differential }\end{array}$ \\
\cline { 2 - 5 }$=\exp (-(\mathrm{Bm}-\mathrm{Bf}) \mathrm{Xf})$ \\
Specification (1) & 0.22 & 0.02 & 0.20 & $81.9 \%$ \\
Specification (2) & 0.22 & 0.04 & 0.18 & $83.5 \%$ \\
Specification (3) & 0.22 & 0.06 & 0.16 & $85.2 \%$ \\
Specification (4) & 0.22 & 0.08 & 0.14 & $86.9 \%$ \\
\hline
\end{tabular}

Panel 2: Using potential experience (age - number of years of schooling - 6) as a proxy

\begin{tabular}{|c|c|c|c|c|}
\hline & $\begin{array}{c}\text { Unadjusted } \\
\text { Differential } \\
\text { (in logs) } \\
\text { (1) } \\
\end{array}$ & $\begin{array}{c}\text { Explained } \\
\text { (differences due to } \\
\text { wage-determining factors) } \\
=(\mathrm{Xm}-\mathrm{Xf}) \mathrm{Bm} \\
(2)\end{array}$ & $\begin{array}{c}\text { Unexplained } \\
\text { (differences due to returns to } \\
\text { wage-determining factors) } \\
=(\mathrm{Bm}-\mathrm{Bf}) \mathrm{Xf} \\
(3)\end{array}$ & $\begin{array}{c}\begin{array}{c}\text { Adjusted } \\
\text { differential }\end{array} \\
=\exp (-(\mathrm{Bm}-\mathrm{Bf}) \mathrm{Xf}) \\
(4)\end{array}$ \\
\hline Specification (1) & 0.22 & 0.02 & 0.20 & $81.9 \%$ \\
\hline Specification (2) & 0.22 & 0.04 & 0.18 & $83.5 \%$ \\
\hline Specification (3) & 0.22 & 0.06 & 0.16 & $85.2 \%$ \\
\hline Specification (4) & 0.22 & 0.08 & 0.14 & $86.9 \%$ \\
\hline
\end{tabular}

\section{Panel 3: Using FYFTE work}

\begin{tabular}{|c|c|c|c|c|}
\hline & $\begin{array}{c}\text { Unadjusted } \\
\text { Differential } \\
\text { (in logs) } \\
\text { (1) } \\
\end{array}$ & $\begin{array}{c}\text { Explained } \\
\text { (differences due to } \\
\text { wage-determining factors) } \\
=(\mathrm{Xm}-\mathrm{Xf}) \mathrm{Bm} \\
(2)\end{array}$ & $\begin{array}{c}\text { Unexplained } \\
\text { (differences due to returns to } \\
\text { wage-determining factors) } \\
=(\mathrm{Bm}-\mathrm{Bf}) \mathrm{Xf} \\
(3)\end{array}$ & $\begin{array}{c}\begin{array}{c}\text { Adjusted } \\
\text { differential }\end{array} \\
=\exp (-(\mathrm{Bm}-\mathrm{Bf}) \mathrm{Xf}) \\
(4) \\
\end{array}$ \\
\hline Specification (1) & 0.22 & 0.04 & 0.18 & $83.5 \%$ \\
\hline Specification (2) & 0.22 & 0.06 & 0.16 & $85.2 \%$ \\
\hline Specification (3) & 0.22 & 0.08 & 0.140 & $86.9 \%$ \\
\hline cification (4) & 0.22 & 0.10 & 0.12 & $88.7 \%$ \\
\hline
\end{tabular}

Note: Adjusted differential refers to the female's earnings as a percentage of male earnings after controlling for differences in observable characteristics. To convert the reported differences in mean log earnings to ratios of female to male earnings the following calculation is performed: ratio $=\exp ($-unexplained $)$.

The sample size is 28,303 observations. 
Appendix 3, Table 2: Accounting for the gender wage gap using age, potential experience and actual

\section{Panel 1: Using age as a proxy for}

\begin{tabular}{|c|c|c|c|c|}
\hline \multirow[b]{2}{*}{ Factors explaining the gap } & \multicolumn{4}{|c|}{$\begin{array}{c}\text { Fraction of gender wage gap explained by ... } \\
\text { Specification }\end{array}$} \\
\hline & 1 & 2 & 3 & 4 \\
\hline Education level*major field of study & 2.5 & 4.1 & 6.1 & 3.7 \\
\hline Age as a proxy for experience & 0.5 & 0.5 & 0.4 & 0.4 \\
\hline Tenure & 4.6 & 3.1 & 2.8 & 2.5 \\
\hline Age of youngest family member & 0.8 & 0.6 & 0.5 & 0.6 \\
\hline Marital status & 0.9 & 0.7 & 0.8 & 0.8 \\
\hline Part-time status & & 8.6 & 7.0 & 3.4 \\
\hline Region & & -0.1 & -0.1 & -0.1 \\
\hline CMA / urban size & & -0.4 & -0.4 & -0.6 \\
\hline Union status & & 0.6 & 0.9 & 0.8 \\
\hline Firm size & & 1.1 & 1.1 & 0.9 \\
\hline Duties & & & 5.6 & 4.7 \\
\hline Influence budget and staffing decisions & & & 2.1 & 1.3 \\
\hline Industry & & & & 11.4 \\
\hline ــcupation & & & & 81 \\
\hline Total explained & 9.3 & 18.8 & 26.8 & 37.9 \\
\hline Total unexplained & 907 & 812 & 732 & 621 \\
\hline Total & 1000 & 1000 & 1000 & 1000 \\
\hline
\end{tabular}

Panel 2: Using potential experience as a proxy for actual

\begin{tabular}{|c|c|c|c|c|}
\hline \multirow[b]{2}{*}{ Factors explaining the gap } & \multicolumn{4}{|c|}{$\begin{array}{l}\text { raction of gender wage gap explained by .... } \\
\text { Specification }\end{array}$} \\
\hline & 1 & 2 & 3 & 4 \\
\hline Education level*major field of study & 1.9 & 3.6 & 5.7 & 3.0 \\
\hline Potential experience & 0.6 & 0.6 & 0.5 & 0.6 \\
\hline Tenure & 5.1 & 3.5 & 3.1 & 2.7 \\
\hline Age of youngest family member & 0.5 & 0.4 & 0.3 & 0.4 \\
\hline Marital status & 0.9 & 0.7 & 0.7 & 0.7 \\
\hline Part-time status & & 8.5 & 6.8 & 3.3 \\
\hline Region & & -0.1 & -0.1 & -0.1 \\
\hline CMA / urban size & & -0.4 & -0.4 & -0.6 \\
\hline Union status & & 0.6 & 0.9 & 0.8 \\
\hline Firm size & & 1.1 & 1.1 & 0.9 \\
\hline Duties & & & 5.6 & 4.8 \\
\hline Influence budget and staffing decisions & & & 2.2 & 1.3 \\
\hline Industry & & & & 11.2 \\
\hline Accupation & & & & 80 \\
\hline Total explained & 9.0 & 18.5 & 26.4 & 37.0 \\
\hline TotaL unexplained & 910 & 81.5 & 736 & 63.0 \\
\hline Total & 1000 & 1000 & 1000 & 1000 \\
\hline
\end{tabular}

\section{Panel 3: Using FYFTE work}

\begin{tabular}{|c|c|c|c|c|}
\hline \multirow[b]{2}{*}{ Factors explaining the gap } & \multicolumn{4}{|c|}{$\begin{array}{c}\text { Fraction of gender wage gap explained by ... } \\
\text { Specification }\end{array}$} \\
\hline & 1 & 2 & 3 & 4 \\
\hline Education level*major field of study & 1.9 & 3.6 & 5.6 & 3.7 \\
\hline FYFTE experience & 11.9 & 11.8 & 10.6 & 10.2 \\
\hline Tenure & 4.3 & 2.7 & 2.4 & 2.2 \\
\hline Age of youngest family member & 0.9 & 0.8 & 0.6 & 0.7 \\
\hline Marital status & 0.9 & 0.7 & 0.8 & 0.8 \\
\hline Part-time status & & 8.4 & 6.8 & 3.3 \\
\hline Region & & -0.1 & -0.1 & -0.1 \\
\hline CMA / urban size & & -0.5 & -0.4 & -0.7 \\
\hline Union status & & 0.6 & 0.9 & 0.8 \\
\hline Firm size & & 1.1 & 1.1 & 0.9 \\
\hline Duties & & & 5.5 & 14.6 \\
\hline Influence budget and staffing decisions & & & 2.0 & 1.2 \\
\hline Industry & & & & 11.1 \\
\hline Occupation & & & & 79 \\
\hline Total explained & 19.9 & 29.1 & 35.8 & 56.6 \\
\hline Total unexplained & 80.1 & 70.9 & 64.2 & 43.4 \\
\hline Total & 100.0 & 100.0 & 100.0 & 100.0 \\
\hline
\end{tabular}




\section{References}

Baker, Michael, Dwayne Benjamin, Andreé Desaulniers and Mary Grant (1995). 'The distribution of the male/female earnings differential, 1970-1990.' Canadian Journal of Economics, vol. 28, no. 3 , p.479-500.

Christofides, L. and R. Swidinsky (1994). 'Wage Determination by Gender and Visible Minority Status: Evidence from the 1989 LMAS.' Canadian Public Policy, vol. 20, no. 1, p.34-51.

Coish, David and A. Hale (1995). 'The wage Gap Between Men and Women: An Update.' SLID Research Paper Series, Statistics Canada, Catalogue no. 75F0002M, 95-14.

Corcoran, Mary and Greg Duncan (1979). 'Work History, Labour Force Attachment and Earnings Differences Between the Races and the Sexes.' Journal of Human Resources, 14, no. 1, p 3 20.

Cromption, Susan and Leslie Geran (1995). 'Women as main wage earners'. Perspectives on Labour and Income, Statistics Canada. Catalogue no. 75-001E. Winter 26-29.

Doiron, D. and C. Riddell (1994). 'The Impact of Unionization on Male-Female Earnings Differences in Canada', Journal of Human Resources, V.29, no. 2 p. 504-35.

The Earnings of Men and Women, Statistics Canada, 1997 Catalogue no. 13-217-XIB.

Finnie, R. and T. Wannell (1999). 'The Evolution of the Gender Earnings Gap Amongst Canadian University Graduates', mimeo, School of Policy Studies at Queen's University.

Gunderson, Morley (1998). Women and the Canadian Labour Market: Transition Towards the Future. Statistics Canada, Census Monograph Series, Catalogue Number 96-321-MPE No. 2.

Gunderson, Morley and Craig Riddell (1993). Labour Market Economics: Theory, Evidence and Policy in Canada. Toronto: McGraw Hill.

Marshall, K. (1999). Perspectives on Labour and Income, Statistics Canada, Catalogue no. 75-001XPE.

Meng, Ronald (1990). 'Union Effects on Wage Dispersion in Canadian Industry.' Economics Letters, Volume 32, Number 4, April, pp. 399-403.

Morissette, René (1991). 'Canadian Jobs and Firm Size: Do Small Firms Pay Less?' Analytical Studies Branch Research Paper Series, No. 35, Statistics Canada.

Murphy, K. and F. Welch (1990). 'Empirical Age-Earnings Profiles', Journal of Labour Economics, Vol. 8 (2), pp. 202-289. 
Wannell, T. (1989). 'The Persistent Gap: Exploring the Earnings Differential Between Recent Male and Female Post-secondary Graduates', Analytical Studies Branch Research Paper Series, No. 26, Statistics Canada.

Wannell, T. and N. Caron (1994). 'The Gender Earnings Gap Among Recent Post-secondary Graduates', Analytical Studies Branch Research Paper Series, No. 68, Statistics Canada. 